\title{
Key geological characteristics of the Saida-Tyr Platform along the eastern margin of the Levant Basin, offshore Lebanon: implications for hydrocarbon exploration
}

\author{
Fadi H. Nader ${ }^{1,}$, Lama Inati ${ }^{2}$, Ramadan Ghalayini ${ }^{3}$, Nicolas Hawie ${ }^{4}$, and Samer Bou Daher ${ }^{5}$ \\ ${ }^{1}$ Division of Geosciences, IFP Energies nouvelles, 1-4 av. Bois-Préau, 92852 Rueil-Malmaison Cedex, France \\ 2 National Center for Geophysical Research, CNRS, Bhannes, P.O. Box:16-5432 - El Metn, Lebanon \\ ${ }^{3}$ Independent Consultant, Ghalayini offices, Sadat Street, Beirut, Lebanon \\ ${ }^{4}$ Beicip-Franlab, 232 av. Napoleon Bonaparte, 92500 Rueil-Malmaison, France \\ ${ }^{5}$ Department of Geosciences and Natural Resource Management, University of Copenhagen, Øster Volgade 10, \\ 1350 Copenhagen, Denmark
}

Received: 7 April 2018 / Accepted: 23 July 2018

\begin{abstract}
More than 60 trillion cubic feet (Tcf) of natural gas have been recently discovered in the Levant Basin (eastern Mediterranean region) offshore Cyprus, Egypt and Israel, Palestine. Un-explored areas, such as the Lebanese offshore, may yield additional discoveries. This contribution focuses the Saida-Tyr Platform (STP), an offshore geological feature adjacent to the southern Lebanese coastline - part of the eastern margin of the Levant Basin. First, an extensive synthesis of recent published research work, tackling crustal modeling, structural geology and stratigraphy will be presented. Then, a new local crustal model and the interpretation of seismic reflection specifically on the STP are discussed and emplaced in the context of the upcoming petroleum exploration activities in this region. Characteristic structural features form the limits of the STP which is believed to be an extension of the Arabian continent into the Levant Basin. Its westernmost limit consists of the extension of the crustal interface, previously termed "hinge zone", where major plate-scale deformations are preferentially localized. The northward extension of this "hinge zone" beyond the STP can be mapped by means of major similar deformation structures (i.e. S-N-trending anticlines) and can be associated to the Levant Fracture System (LFS) - the northwestern border of the Arabian plate. The northern limit of the STP (i.e. the Saida Fault) is a typical E-W, presently active, structure that is inherited from an older, deeply rooted regional fault system, extending eastward throughout the Palmyra Basin. The STP is characterized by a variety of potential plays for hydrocarbon exploration. Jurassic and Cretaceous clastics and carbonates are believed to include reservoir plays, which could have been charged by deeper Mesozoic source rocks, and sealed by Upper Cretaceous marly layers. The edge of the Cretaceous carbonate platforms and potential carbonate buildups are well recognizable on seismic reflection profiles. The western and northern anticlinal structures bordering the STP are excellent targets for Oligo-Miocene biogenic gas charging systems. Based on integrating geodynamics, tectono-stratigraphic interpretations and petroleum systems analyses, such plays are well constrained and the exploration risk is therefore lowered.
\end{abstract}

\section{Introduction}

The eastern Mediterranean region has proven to be a worldclass, frontier deepwater hydrocarbon province with major gas discoveries. More than 60 trillion cubic feet (Tcf) of natural gas were discovered offshore Israel, Cyprus and Egypt, including the Tamar field (the world's largest deepwater

\footnotetext{
* Corresponding author: fadi-henri.nader@ifpen.fr
}

natural gas discovery in 2009). Zohr field was discovered in offshore Egypt in 2015, making the largest ever natural gas find in the Mediterranean Sea. More recently, Calypso discovery, which was announced early 2018 offshore Cyprus, confirms the extension of Zohr-like play within the East-Mediterranean region. New plays have further been proposed, and un-explored areas, such as the Lebanese offshore, may yield additional discoveries (Fig. 1). Modern seismic acquisitions and interpretations place the Levant 

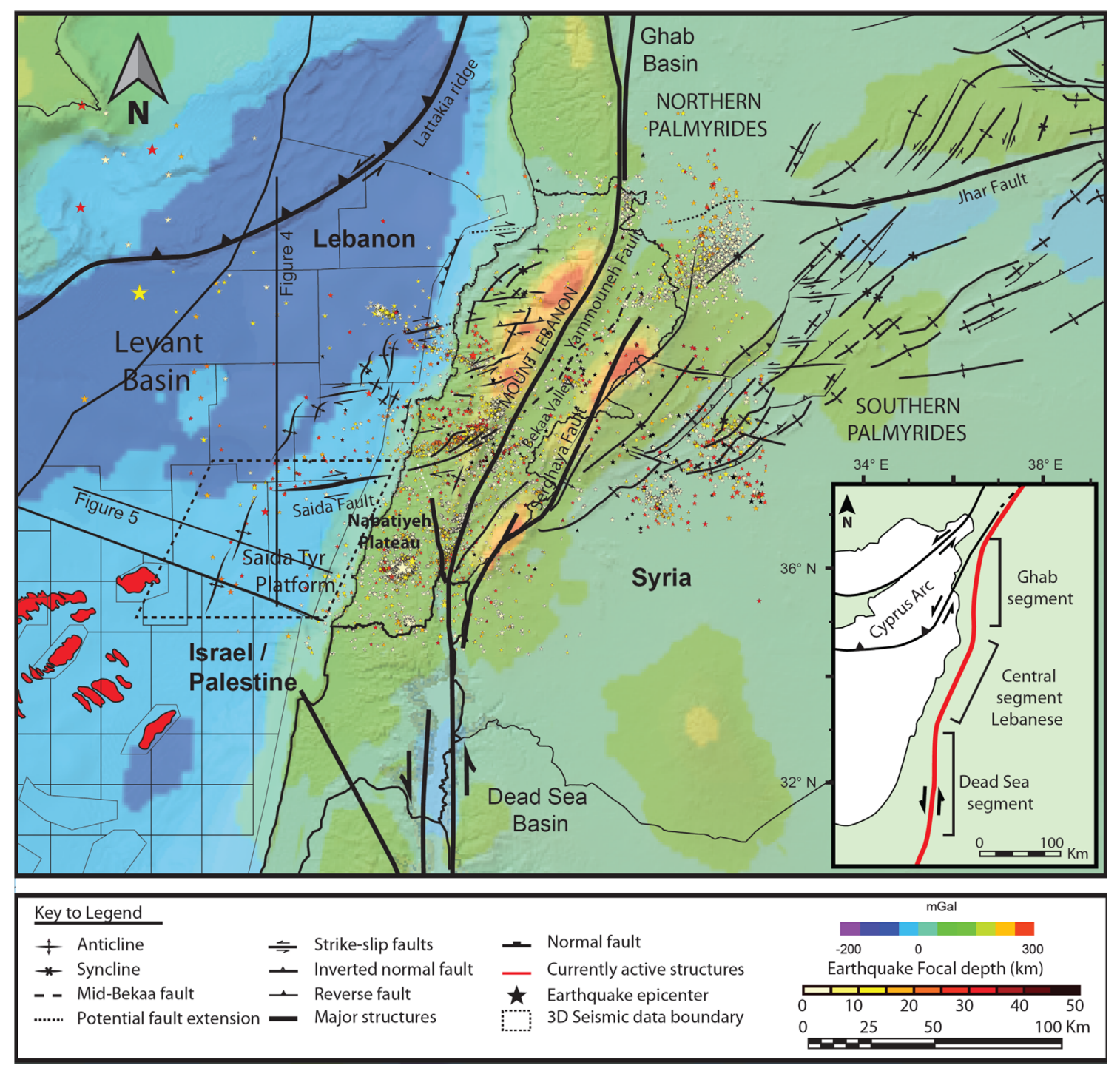

Fig. 1. The major structures of the Levant margin and the adjacent Palmyra Basin on TOPEX Free-Air Gravity map background the mapped structures are based on Ghalayini et al. (2014) and published data (e.g. Brew et al., 2001). The earthquake epicenters are taken between 2006 and 2013 and are from www.cnrs.com.lb.

Basin as a "natural laboratory" for improving numerical modeling workflows and techniques for better exploring sedimentary basins.

Recent research projects, focusing on the northern part of the Levant Basin, provided substantial new data and concepts for better understanding the crustal, structural, and stratigraphic characteristics of this region, as well as its key petroleum systems (e.g. Hawie et al., 2015; Bou Daher et al., 2016; Inati et al., 2016, 2018; Ghalayini et al., 2017a, 2017b, 2018; Symeou et al., 2017; Grohmann et al., 2018; Papadimitriou et al., 2018a, 2018b). These studies also led to the distinction between the basin and the margins of the Levant. Two parts of the central-eastern Levant margin have been documented: (i) a dominantly aggrading carbonate margin on- and offshore northern Lebanon; and (ii) a southern sector, with a prominent extension of the Levant margin platform with a thinner sedimentary cover (Ghalayini et al., 2014; Hawie et al.,
2014). This outstanding feature along the southern part of the central-eastern Levant margin is the Saida-Tyr Platform (STP), which is the subject of this contribution. The STP consists of a $60 \mathrm{~km}$ wide elevated terrain that lies between $200 \mathrm{~m}$ and $1700 \mathrm{~m}$ below sea level (Fig. 1). It is delimited to the north and west by steep faults observed on seismic profiles (e.g. Hawie et al., 2013; Ghalayini et al., 2014). The most prominent of these faults is the $60 \mathrm{~km}$ long Saida fault, which marks a sharp transition between the margin and the deep basin. The morphological differentiation between the STP and its surroundings is manifested by a thicker crust compared to the rest of the basin particularly north of Saida fault, as implied by the gravity map. Several geological aspects of the STP, however, remain poorly understood and require more in-depth analysis. In particular, more work is needed to unravel the geological nature of the STP and its petroleum systems. 
The aim of this contribution is to enhance the characterization of the Levant margin, offshore Lebanon, in general, and the STP in particular. Subsequently, the proposed goals are to understand the geological nature of the STP while identifying and diversifying potential plays to de-risk exploration in the Levant Basin. Through this work, we present new data for characterizing the crustal configuration, the main structural styles and the stratigraphic patterns of the STP, being part of the eastern Levant Margin. The associated elements of potential petroleum systems are furthermore discussed in the framework of an integrated geology and geophysics (G\&G) study.

\section{Geological setting}

\subsection{Structural evolution}

The northwestern part of the Arabian Plate is characterized by a steady decrease of the Moho depth from about $39 \mathrm{~km}$ to around $26 \mathrm{~km}$ at the easternmost coastline of the Mediterranean Sea (Ginzburg et al., 1979, 1994; El-Isa et al., 1987; Weber et al., 2004). This has been interpreted to represent a thinning of the continental crust towards the Mediterranean Sea with a thickening of the overall sedimentary pile in the same direction. Additional seismic refraction data, which were acquired in the southern part of the Levant Basin, revealed that the depth of the Moho further decreases towards the center of the basin - i.e. offshore Egypt, Israel, Cyprus and Lebanon - and reaches about $22 \mathrm{~km}$ (Makris et al., 1983; Ben-Avraham et al., 2002; Weber et al., 2004; Zverev 2005; Netzeband et al., 2006). The southeastern margin of the Levant Basin is characterized by thinning of the lower and upper crustal segments (Segev et al., 2006). Chamot-Rooke et al. (2005) also suggested that the basin comprises a series of en-echelon oceanic sub-basins, possibly separated by thinned continental crust, which formed in Cretaceous times.

The hypothesis of a thin continental crust flooring the Levant Basin was supported by refraction studies (e.g. Netzeband et al., 2006), and more recently demonstrated by geophysical modeling (Inati et al., 2016, 2018). Henceforth, it is represented by two layers, an upper and a lower crust without any discontinuity within the onshore-offshore transition discarding any change in the crustal nature. Inati et al. (2016) demonstrated that the thinning of the crust at the Levant margin, in the transitional domain between the onshore and the offshore, is gradual, indicating successive regimes of extension that did not reach the break up stage. Such extension is very likely the origin of the initiation of the eastern Mediterranean basins and associated with the Tethyan rifting in Permo-Triassic times. Indeed, the Levant Basin and the nearby Palmyra Basin (onshore, Fig. 1) are believed to have formed during multiple phases of rifting of Permo-Triassic/Jurassic age (e.g. Nader, 2014; Ghalayini et al., 2017b).

The collision of the Afro-Arabian and Eurasian plates as of the Late Cretaceous times and throughout the Cenozoic, caused inversion of pre-existing extensional structures in the northwestern part of Arabia and northern Africa
(Frizon De Lamotte et al., 2011) (Fig. 1). Yet, the present-day structural framework of the eastern Levant margin is dominated by the Levant Fracture System (LFS; Fig. 1), a regional sinistral strike-slip fault system extending from the Gulf of Aqaba (Red Sea) to the Taurus mountains in Turkey, forming the Arabia-Africa plate boundary (Freund et al., 1970; Dubertret, 1972). Strike-slip motion across the LFS is believed to have occurred initially in middle Miocene times in the southern Dead Sea segment (Quennell, 1958; Freund et al., 1970; Garfunkel, 1998), in the Late Miocene in the central Lebanese segment (Homberg et al., 2010), and in the Pliocene in the northern Ghab segment (Al Abdalla et al., 2010; Searle et al., 2010). Displacement on the LFS in Lebanon was in general transpressional during the Late Miocene resulting in a restraining bend and causing uplift of pre-existing structures (Butler et al., 1998; Gomez et al., 2006). From the Pliocene to present day, the fault has accommodated mainly sinistral strike-slip displacement with no apparent folding (Daeron et al., 2004; Gomez et al., 2006; Homberg et al., 2010). Transpression and strike-slip tectonics are also accommodated by the sinistral strike-slip Roum and Serghaya faults which branch from the southern LFS (Butler et al., 1998; Gomez et al., 2001) (Fig. 1). The Roum fault borders the Nabatiyeh Plateau, an onshore structure that merges westwards with the offshore Saida-Tyr Platform (STP; Fig. 1).

A number of ENE-WSW, currently active, dextral strike-slip faults occur along Mount Lebanon (Gedeon, 1999) and extend into the Levant margin offshore (Ghalayini et al., 2014). These faults developed most likely during the Early Mesozoic as normal faults during the Tethyan rifting, and were subsequently reactivated from the Late Cretaceous to the Neogene compression (Collin et al., 2010; Ghalayini et al., 2014). They are observed to crosscut N-E trending folds both offshore and onshore by about 1 or $2 \mathrm{~km}$, right-laterally (Ghalayini et al., 2017b). The ENE-WSW faults are active at present day as also evidenced by clustering of earthquake epicenters (Fig. 1). A zone of intense faulting, referred to as the Damour fault, between the Damour coast and the Dahr Al-Baidar gap is documented based on field observation and is believed to separate the two structural zones of northern and southern Mount Lebanon (Hancock and Atiya, 1979). The westward, offshore extension of the Damour Fault could be the dextral strike-slip Saida fault (northern limit of STP, mentioned above), based on their similar styles and strike orientations (Ghalayini et al., 2014) (Fig. 1).

\subsection{Stratigraphic succession}

The Late Paleozoic/Early Mesozoic rifting, mentioned above, led to the formation of a passive margin with dominantly aggrading carbonate platforms (Fig. 2; Hawie et al., 2014). The post-rift phase initiated around the Middle Jurassic, and resulted in an overall increase in subsidence along the Levant region and the development of an epicontinental shelf until the Kimmeridgian (Collin et al., 2010). Jurassic to Tertiary rock successions are exposed onshore Lebanon, presenting an overall average thickness of about $5000 \mathrm{~m}$ (Nader et al., 2016). These successions 


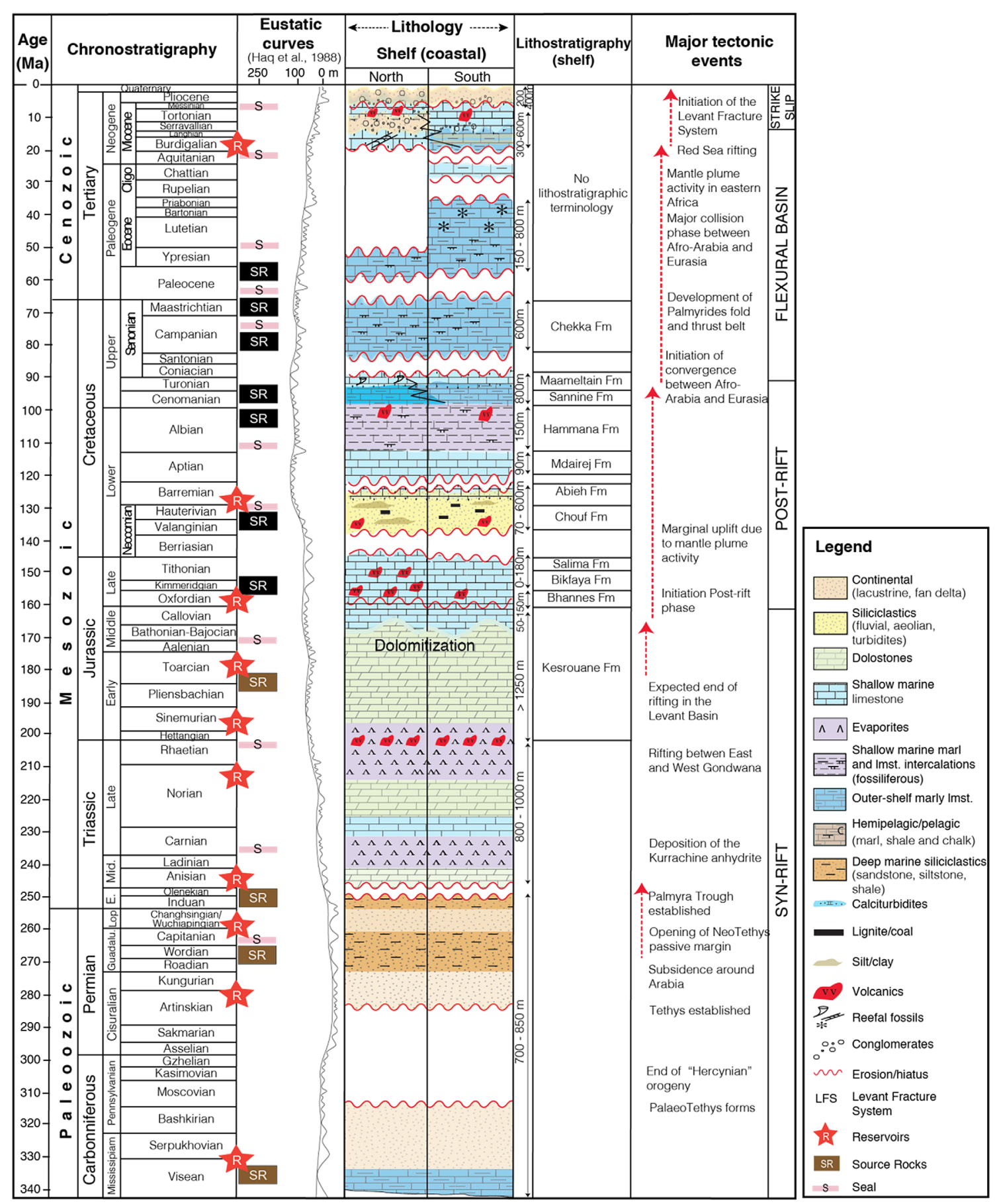

Fig. 2. General chronostratigraphic chart of the Levant margin (on- and offshore Lebanon) showing the major formations, sedimentary facies and hiatuses. Principal tectonic events are also shown as well as the elements of potential petroleum systems.

include shallow-marine carbonates, shales, marls, sandstones, siltstones and volcanics (Fig. 2). The underlying (pre-Jurassic) sedimentary successions onshore Lebanon can only be deduced based on regional correlations and could reach an estimated average thickness of about 2000-3700 $\mathrm{m}$ in northern Lebanon (Renouard, 1955; Beydoun, 1977) (Fig. 1). The deepest seismic reflector interpreted onshore Lebanon is believed to relate to the Middle or base Triassic level (Fig. 2) and might correspond to the
Kurrachine evaporate unit, a major seal in the Palmyra Basin (Nader et al., 2016).

The stratigraphic characteristics of the Levant margin vary from south to north along the Lebanese coastline. The Adloun-1 well is located in southern Lebanon, adjacent to the STP and has revealed a very thick Cetaceous carbonate sequence (Fig. 3). The basal Cretaceous Chouf sandstone Formation is $170 \mathrm{~m}$ thick, sits on a regional unconformity, and underlies the Mdairij carbonate 


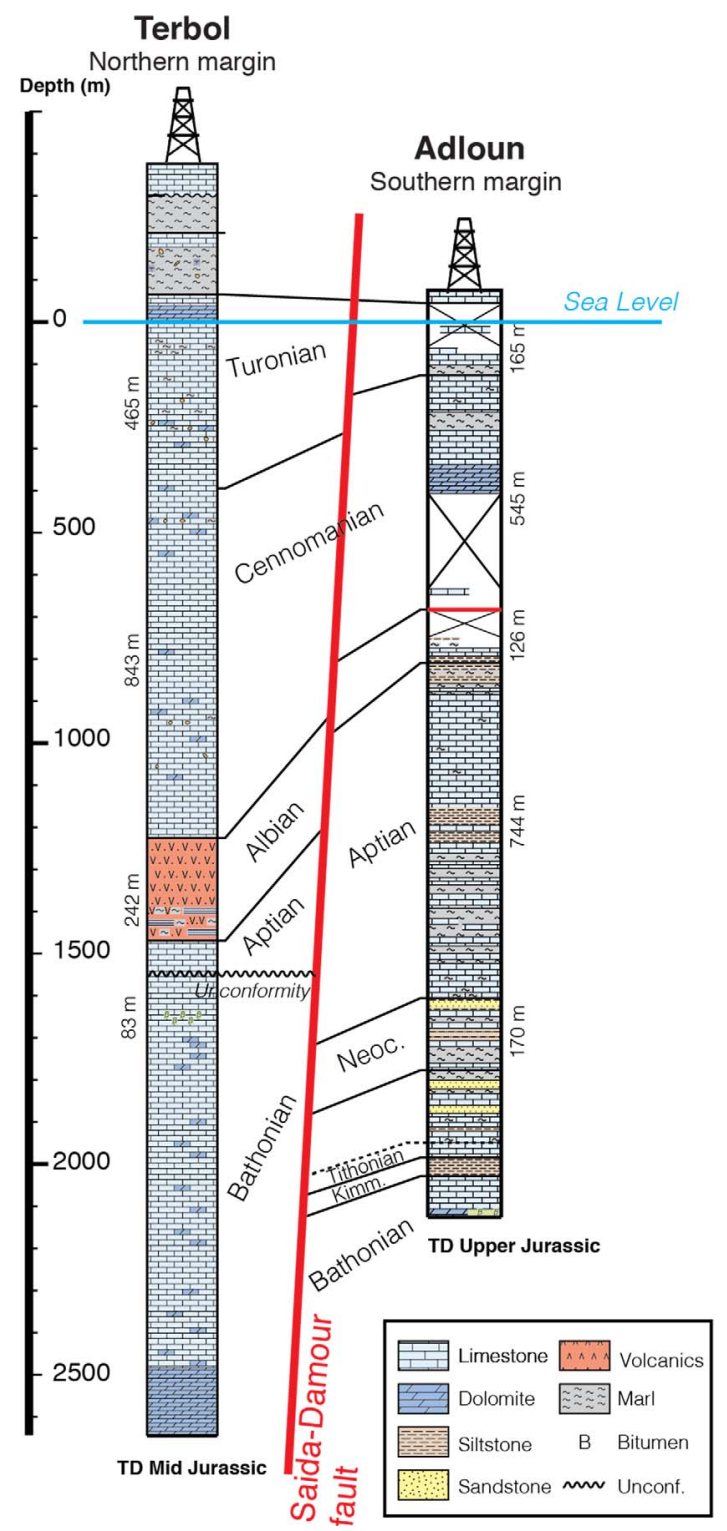

Fig. 3. Stratigraphic logs and correlation between Terbol-1 (north) and Adloun-1 (south) coastal wells showing the thickness variation of the variation of Cretaceous sequences between the northern and southern margins of Lebanon. These wells are the most proximal to the eastern margin of the Levant Basin (for locations check Figs. 1 and 9). Modified from Ukla (1970) and Beydoun (1977).

Formation which is $774 \mathrm{~m}$ thick. In the Terbol well, the Chouf sandstones are absent and the Lower Cretaceous carbonates are only $83 \mathrm{~m}$ thick (Fig. 3). The onshore Nabatiyeh Plateau (east of Adloun-1 well) and the nearby STP, together illustrating the typical southern Levant margin, include the Chouf sandstones, which consists of organic-rich intervals as well as potentially good reservoirs (Ghalayini et al., 2018). These are overlain by thick shallow marine carbonate sequences capped by the Late Cretaceous pelagic limestones and marls (typical regional seal and source rock; Bou Daher et al., 2016; Fig. 2). The Albian, Cenomanian and Turonian units also show thickness variations between south and north Lebanon, whereby they consist of an overall $836 \mathrm{~m}$ thick sequence in the Adloun-1 well, compared to $1550 \mathrm{~m}$ thick equivalent sequence in the Terbol well (Fig. 3). This thickness variation could be related to regional effects on basin development along the Levant margin throughout Cretaceous times and/or potential structural control by the E-W Saida-Damour fault and other E-W faults. E-W facies trend was also attested onshore Lebanon for the Cenomanian-Turonian rock series with shallow marine reefal settings passing into deeper marine outer shelf environments towards the coastal areas (Dubertret, 1972; Saint-Marc, 1975). The Cretaceous carbonate platforms are expected to extend into the offshore reaching much deeper depositional settings in the distal part of the Levant Basin (Hawie et al., 2014).

Continuous drowning, in the Late Cretaceous, led to the deposition of chalky and marly limestones of the Chekka Formation, which was identified on offshore seismic profiles by intervals with lower amplitudes (e.g. Hawie et al., 2013). Onshore, the Senonian/Campanian-Maastrichtian Chekka Formation is $100-500 \mathrm{~m}$ thick, with the thickest succession documented in the southern Bekaa valley. This formation is well documented along the Levant margin onshore and offshore (Bou Daher et al., 2014; Ghalayini et al., 2018; Hawie et al., 2014). Organic-rich argillaceous limestones with TOC values between $2 \%$ and $10 \%$, with higher values in South Lebanons (Hasbaya locality), make out of the Chekka Formation a potential source rock (Bou Daher et al., 2014, 2015).

The overlying Paleocene units are $300 \mathrm{~m}$ thick and consist of chalky limestones and marls. Nummulitic middle Eocene limestones have been documented in the Bekaa Valley (Dubertret, 1955) where they are up to $900 \mathrm{~m}$ thick (Hawie et al., 2014), and in south Lebanon. Upper Eocene and Oligocene units are absent onshore Lebanon due to uplift and erosion of the Levant margin during Early Miocene compression (Walley, 1998), except for one local outcrop in the south of Lebanon (Müller et al., 2010). The middle Miocene at outcrop consists of continental lacustrine facies in the Bekaa Valley and, by contrast to open-marine facies along the margin (Dubertret, 1955) that could likely form isolated reef structures (Hawie et al., 2014). An angular unconformity was identified between the Lower Eocene and the Burdigalian onshore northern Lebanon. The rhodalgal Middle Miocene presents E-W and N-S lateral facies variations (Hawie et al., 2014, 2015) with deeper settings localized towards central Lebanon.

The stratigraphy of the Levant Basin is based on seismostratigraphic interpretation and correlations with field investigations (Hawie et al., 2013). The sedimentary pile in the basin is expected to reach up to $12 \mathrm{~km}$ of Mesozoic and Cenozoic sediments (Fig. 4). Thickening trends attested in the Cretaceous to Oligocene offshore northern Lebanon point to the impact of subduction on the structuration of the northern Levant Basin along the Lattakia Ridge (part of the Cyprus Arc system; $c f$. Fig. 1), followed by a thick deposition of deep water sediments onlapping on the dominantly aggrading margin. At the southern part 


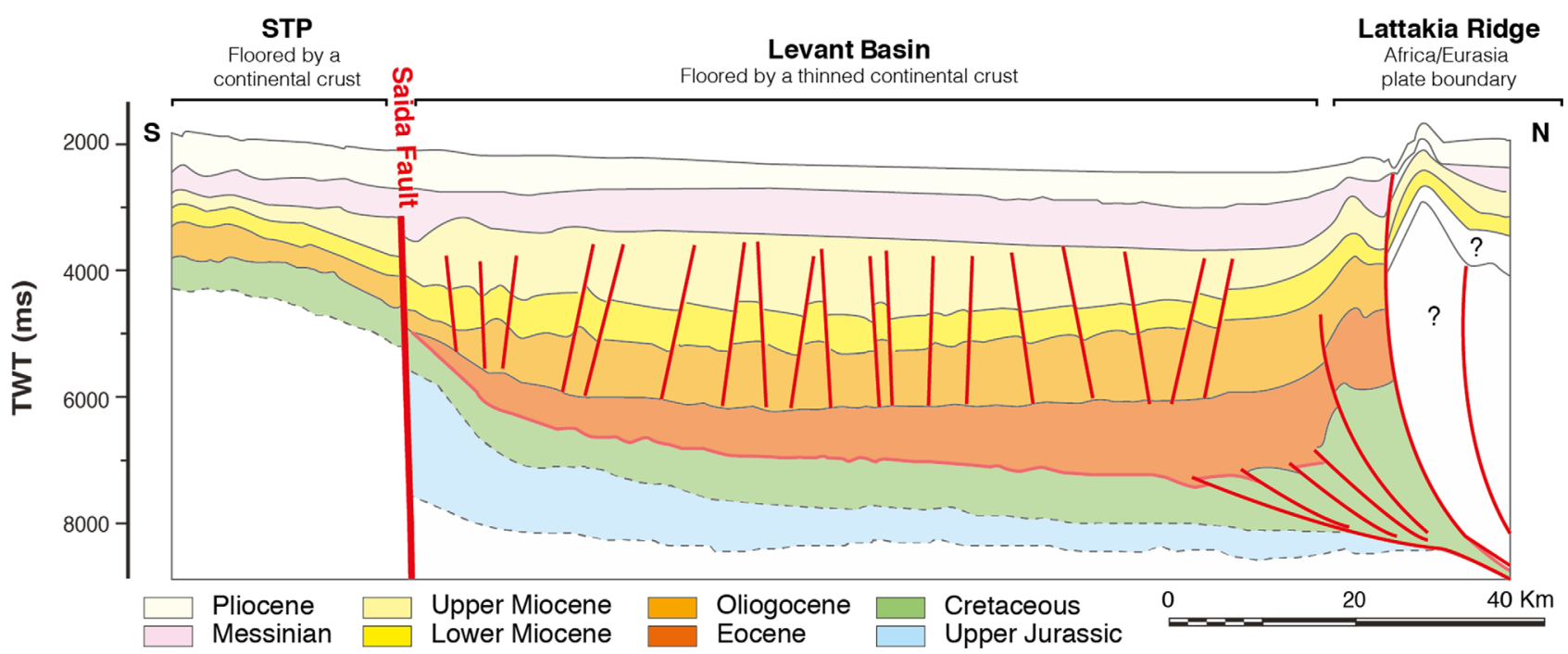

Fig. 4. N-S interpreted seismic section along the STP, Levant Basin and Lattakia Ridge showing the general tectono-stratigraphic architecture of the basin. The STP is separated from the Levant Basin by the Saida fault, marking a sharp contrast between the basin and its southern margin. See Figure 1 for location. Modified from Hawie et al. (2014) and Ghalayini et al. (2014).

of the basin, an abrupt transition from basin to margin is observed, in which the sedimentary pile over the STP does not exceed $6 \mathrm{~km}$ in thickness (Fig. 4). The separation takes place along the Saida fault. The whole system is capped by the Messinian evaporites with thicknesses exceeding $1500 \mathrm{~m}$ which are overlain by the Plio-Quaternary clastics following the inundation of the Mediterranean (Fig. 4).

Various seismic facies (channels, lobes) are identified on the seismic data offshore Lebanon pointing to a multisource clastic influx of sediments from the margin into the basin (Fig. 5) (i.e. Nile, Latakia, Arabian Shield/Levant margin; Hawie et al., 2013, 2015). The variability of documented seismic facies helps in assessing the evolution of the Levant Basin depositional environments through the Mesozoic and Cenozoic times. Seismic interpretations led to a generalized conceptual sedimentological model which illustrates the northern Levant Basin architecture and facies distribution (Fig. 6) (Hawie et al., 2014). By proposing this conceptual model (Fig. 6), not only the facies can therefore be predicted and linked to the accessible data on offshore wells (e.g. Tamar) and onshore outcrops, but also some insights on the sediment inputs and carbonate buildups can be proposed based on source-to-sink and known carbonate factories. Consequently, the facies documented onshore Lebanon are expected to be present along the margin offshore, but deposited in deeper water environments as discussed above.

\section{Methodology}

\subsection{Crustal modeling}

Based on recent reviews of the geodynamics of the Eastern Mediterranean region, as well as modern geophysical data, interpreted crustal-scale profiles across the STP could be achieved. This was done through numerical modeling taking into account the free-air gravity anomalies (Zeyen and Fernàndez, 1994; Zeyen et al., 2005). Figure 7 shows the location of the modeled section on the topography and the free-air gravity maps.

Free-air gravity anomalies (1-minute grid spacing) are extracted from publicly available worldwide database TOPEX (www.topex.ucsd.edu). A $50 \mathrm{~km}$ wide strip was extracted on both sides of the profile and the values were averaged every $5 \mathrm{~km}$. The variability of data within the strip was considered as data uncertainty (error bars in Fig. 7C). The modeled lithosphere is divided into bodies representing from top to bottom: different layers of sediments, a continental upper crust, a continental lower crust and a lithospheric mantle. The oceanic crust is considered to have similar properties as the lower continental crust. These bodies are characterized by the following rock properties: (1) density and its dependence on temperature and depth, (2) thermal conductivity, and (3) heat production (Tab. 1). The shape, size and characteristics of the bodies are modified interactively in order to find the best-fitting model with the geophysical data used as input. The numerical model combines joint interpretation of thermal and mass distribution related data. The temperature distribution is calculated using a finite element algorithm in two dimensions using the ponderation method (Zienkiewicz, 1977) within the bodies forming the model by equation (1) (Lachenbruch and Sass, 1977):

$$
\nabla(\lambda \nabla T)+A(x, z)=0
$$

where $\lambda$ is thermal conductivity $\left(\mathrm{W} \mathrm{m}^{-1} \mathrm{~K}^{-1}\right), T$ is the temperature $\left({ }^{\circ} \mathrm{C}\right), \nabla=(\mathrm{\partial} / \partial x, \partial / \partial z)$, and $A$ is radiogenic heat production $\left(\mathrm{W} \mathrm{m}^{-3}\right)$.

The following boundary conditions are used for the resolution of the heat transport equation: a constant surface temperature of $0{ }^{\circ} \mathrm{C}$, constant temperature of $1300{ }^{\circ} \mathrm{C}$ at 


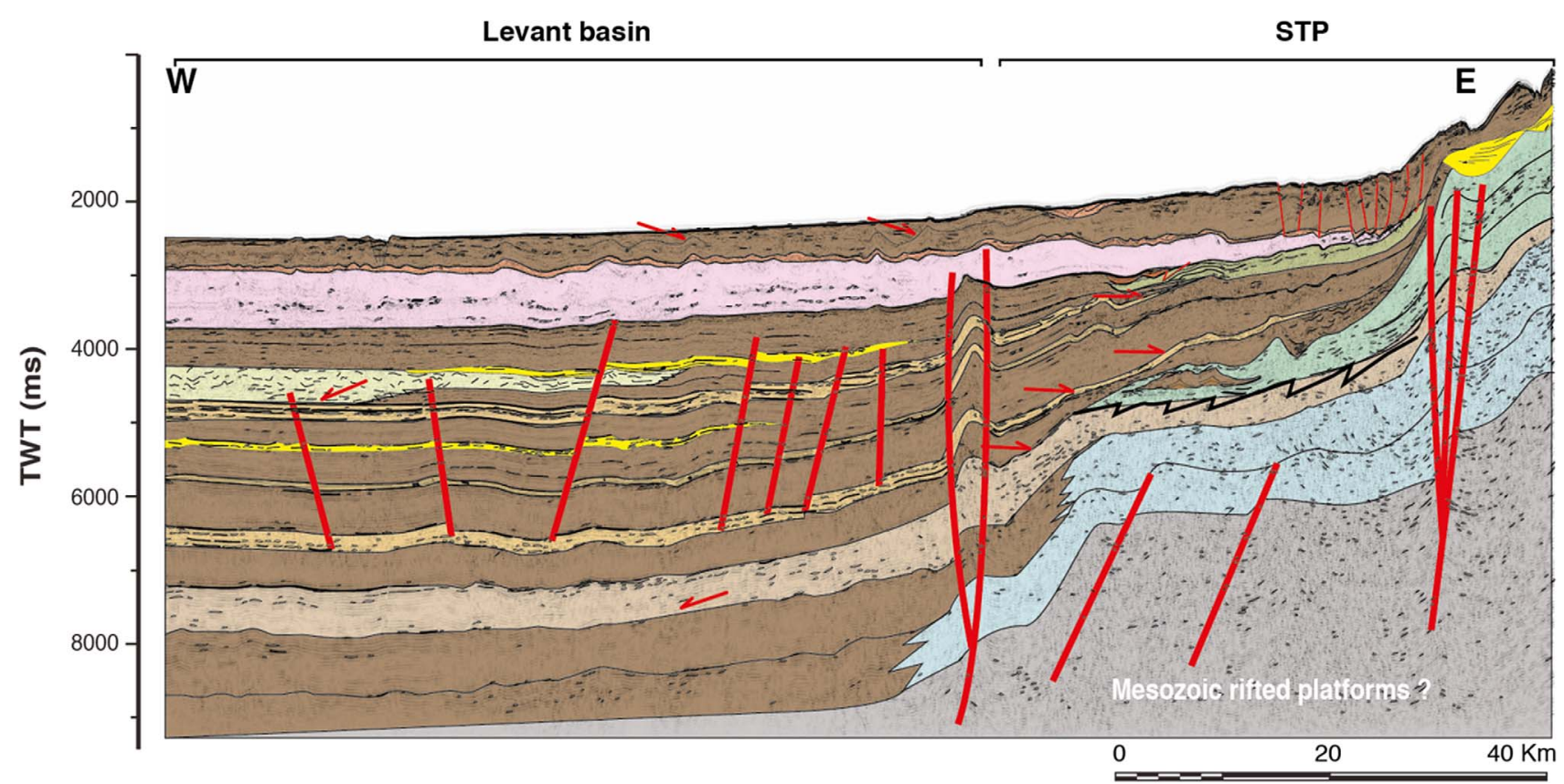

\section{Extensive facies}

Hemipelagic/pelagic deposits

Evaporites

Hemipelagic deposits with high detritic/clastic content

Post-rift carbonate platforms

\section{Localised bodies}

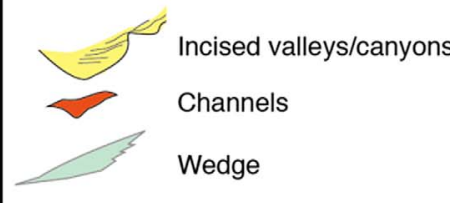

stacked slope channels and turbidite lobes

Rift, syn-rift and earliest post-rift carbonate platforms

Fig. 5. E-W geo-seismic line interpretation from southern Lebanon showing the expected facies variations from east to west. See Figure 1 for location.

the base of the lithosphere and no lateral heat flow across the vertical lateral boundaries are considered. Once the temperature distribution in the lithospheric mantle is determined, the density distribution is calculated as a function of temperature assuming that the density of the lithospheric mantle increases upward with decreasing temperature (Lachenbruch and Morgan, 1990) according to the formula:

$$
\rho_{\mathrm{m}}(z)=\rho_{\mathrm{a}}\left[1+\alpha\left(T_{\mathrm{a}}-T(z)\right)\right]
$$

where $\rho_{\mathrm{m}}(z)$ is the density in the lithospheric mantle $\left(\mathrm{kg} \mathrm{m}^{-3}\right), \rho_{\mathrm{a}}$ is density of the asthenosphere $\left(\mathrm{kg} \mathrm{m}^{-3}\right), \alpha$ is thermal expansion coefficient $\left(\mathrm{K}^{-1}\right), T_{\mathrm{a}}$ is temperature at the lithosphere-asthenosphere boundary $\left({ }^{\circ} \mathrm{C}\right)$ and $T(z)$ is temperature in the lithospheric mantle $\left({ }^{\circ} \mathrm{C}\right)$. A detailed explanation of the algorithm can be found in Zeyen and Fernàndez (1994) and Zeyen et al. (2005).

\subsection{Stratigraphic and structural interpretations}

Seismic interpretation was performed on a high-quality PSDM 3D seismic survey acquired in 2013 by PGS and courtesy of the Lebanese Petroleum Administration. The data covers an area of $3000 \mathrm{~km}^{2}$ and is located offshore southern Lebanon. Two-way time thickness intervals were depth converted based on stacking velocities and interpretation was performed on depth converted profiles.

Key seismic packages and their bounding surfaces were identified (onlap, toplap, downlap and truncations). The seismic facies analysis followed seismic stratigraphic principles presented by Mitchum (1977), Sangree and Widmier (1977), Roksandi'c (1978) and Van Wagoner et al. (1988). The use of such seismic stratigraphic and facies analysis principles allowed to better link the onshore observations and interpretations to the offshore (Hawie et al., 2013-2015; Ghalayini et al., 2018). Proposed interpretations are also supported by published 3D seismic results (e.g. Fürstenau et al., 2013) and fit with the generally accepted regional paleogeographic context.

More than 30 faults were mapped in this study in the offshore region; among which three large deep strike-slip faults and 25 normal faults interpreted in the Mesozoic unit of the STP adjacent to the shoreline. The faults were modeled in 3D in order to understand their geometry and 


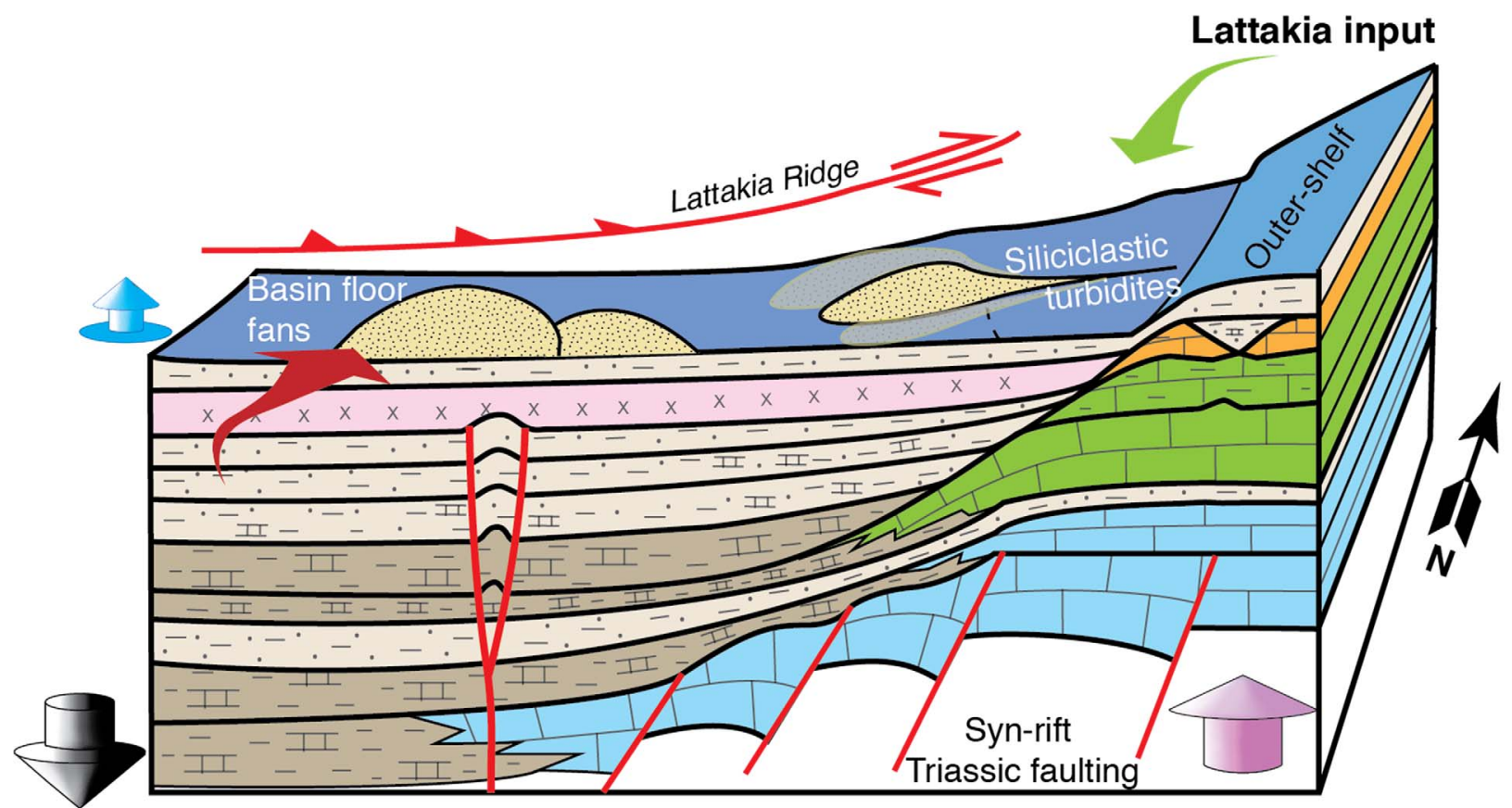

\section{Legend}

\begin{tabular}{|l|l}
\hline $\mathrm{XX}$ & Evaporites \\
\hline$\dot{ } \cdot$ & $\begin{array}{l}\text { Deep water } \\
\text { (mixed system) }\end{array}$ \\
\hline $\mathrm{I}^{-}$ & $\begin{array}{l}\text { Deep water } \\
\text { (carbonate dominated) }\end{array}$
\end{tabular}

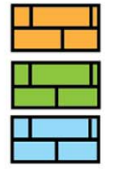
carbonate platforms Cretaceous to Eocene post-rift carbonate platforms

Jurassic syn-rift to early post-rift carbonate plafforms

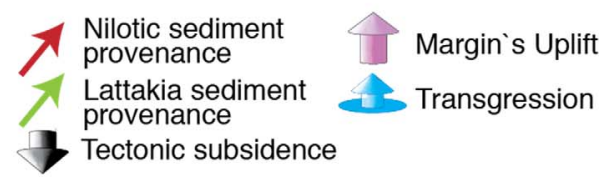

Fig. 6. Generalized conceptual stratigraphic model based on seismic interpretations and correlation with nearby surface exposed strata, showing the margin to basin architecture and stratigraphic evolution in southern Lebanon. Slightly modified from Hawie et al. (2014).

extent. Depth maps, constructed from 3D seismic data, were used to understand the general structure of the margin. In addition, this helped in mapping the trends of major anticlines and in investigating their structural styles.

\section{Results}

\subsection{Crustal modeling}

Free-air gravity anomalies extracted along the profile increase progressively from $-60 \mathrm{mGals}$ in the N-W to reach +60 mGals in the S-E which is in good agreement with the calculated anomalies (less than $8 \mathrm{mGals}$ of uncertainty; Fig. 7). The geophysical model invokes a $20-21 \mathrm{~km}$ thick crust under the STP in the closest part to the coast that thins progressively to reach a thickness of $5-6 \mathrm{~km}$ in the $\mathrm{N}-\mathrm{W}$, in the central part of the basin (Fig. 8). The interpreted Moho is about $19 \mathrm{~km}$ deep in the N-W and deepens to $28 \mathrm{~km}$ close to the coastline. Such Moho depth configuration appears logical with respect to data provided from previous work $(\sim 22 \mathrm{~km}$ in the center versus $\sim 26 \mathrm{~km}$ at the margin of the basin, see above, Sect. 2.1). This crust is of continental nature and is believed to be constituted of a lower part with a density of $2900 \mathrm{~kg} \mathrm{~m}^{-3}$ density and an upper crust with a density of $2750 \mathrm{~kg} \mathrm{~m}^{-3}$. The intersection of the Saida fault with the modeled profile could be well recognized at the distance of $45 \mathrm{~km}$ from the N-W (Figs. 6 and 7C). The Saida fault represents a fracture in the crust and at the same time a smooth transition between a thick crustal part connected to the continent and a thinner crust basinwards.

The crust is overlain by a sedimentary package of thickness varying between $12 \mathrm{~km}$ in the north-western part of the profile and $6 \mathrm{~km}$ on the STP. The sedimentary infill of the basin, which was described in details above (Sect. 2), had to be simplified in the proposed crustal models, while keeping the major density-based subdivision (Fig. 8). Thus, the overall package is divided here into only four layers based on their density variations. Rock properties used for each body in the models for the Levant Basin are summarized in Table 1 . The density of the shallower layer of Plio-Quaternary sediments is represented as a function of depth, since it is considered to be affected by compaction following equation (3) from Cordell (1973):

$$
\rho_{\mathrm{q}}(z)=2600-400 \mathrm{e}^{-z / 2}
$$

where $\rho_{\mathrm{q}}(z)$ is the density of Quaternary sediments and $z$ is depth below surface measured in $\mathrm{km}$.

The density of the Plio-Quaternary sediments varies between $2200 \mathrm{~kg} \mathrm{~m}^{-3}$ and $2600 \mathrm{~kg} \mathrm{~m}^{-3}$. These are 

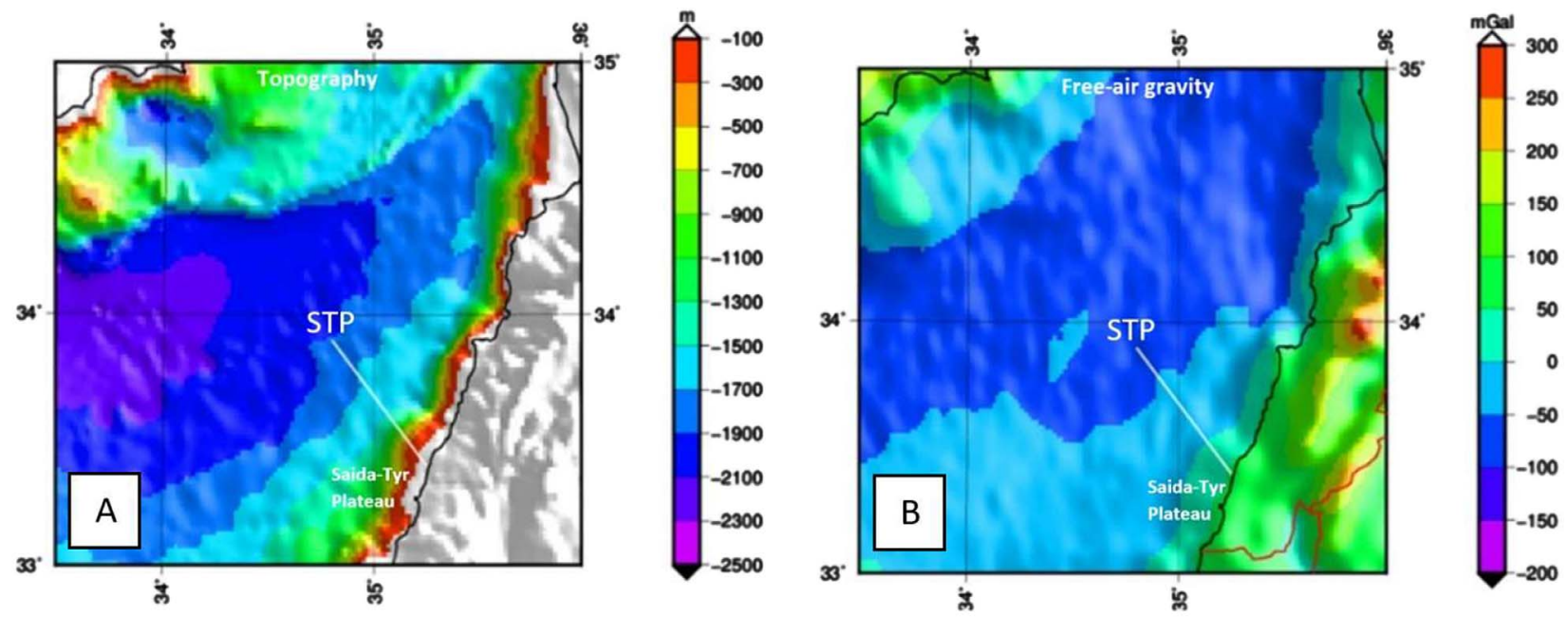

Profile STP (34.8/33.9-35.25/33.4)

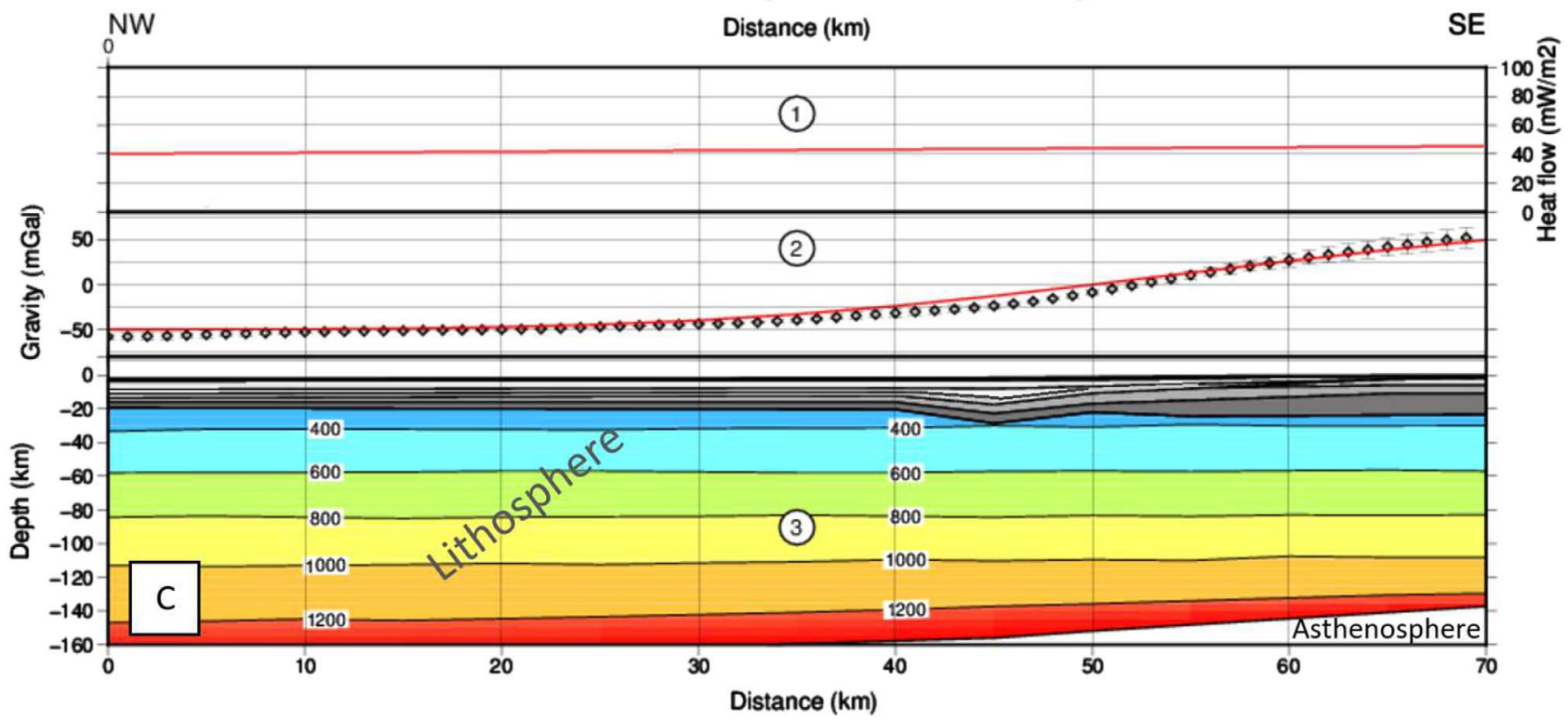

Fig. 7. (A), (B) Location of the modeled cross section STP on the topography and free-air gravity maps, respectively (Topex database); (C) Modeling results for profile STP. Graph C1 shows the calculated heat flow for the model. Graph C2 represents the observed gravity anomaly (diamonds: dots with error bars) and the data calculated for the model shown without vertical exaggeration (solid line). The error bars correspond to the data uncertainty for the standard deviation within a range of $5 \mathrm{~km}$ to each side of the profile. In graph C3, the crust is represented in grey shades and the lithospheric mantle contains the temperature distribution with isotherms every $200{ }^{\circ} \mathrm{C}$ and finally the asthenosphere in white, separated by the Lithosphere-Asthenosphere Boundary (LAB) from the lithosphere.

underlain by a $2 \mathrm{~km}$ thick unit of salt with a density of $2100 \mathrm{~kg} \mathrm{~m}^{-3}$, a layer of $2450 \mathrm{~kg} \mathrm{~m}^{-3}$ consisting of dense Cenozoic siliciclastics, and finally a thick layer of Mesozoic sediments of a constant density of $2550 \mathrm{~kg} \mathrm{~m}^{-3}$ overlying the crystalline crust. This last layer is considered to be compacted enough not to have a density dependent on pressure. Mantle density is a function of temperature and is evaluated in the model after equation (4) from Lachenbruch and Morgan (1990):

$$
3200\left[1+3.5 \times 10^{-5}\left(T_{\mathrm{a}}-T(z)\right)\right] \text { with } T_{\mathrm{a}}=1300{ }^{\circ} \mathrm{C} .
$$

\subsection{Tectono-stratigraphic interpretations}

The Saida fault, which makes the northern limit of the $\mathrm{STP}$, is $60 \mathrm{~km}$ long, trending ENE-WSW and downthrows the Senonian unconformity horizon by about $2 \mathrm{~km}$, to the north. This fault is associated with a mini-basin at its western terminal end, forming what could be referred to as a horsetail structure (Fig. 9). In addition, at least four N-E trending en-echelon anticlines are observed in seismic data adjacent to the fault (Fig. 9). Such observations indicate that the Saida fault is most likely a dextral strike-slip fault. Ghalayini et al. $(2014,2018)$ provide an analogy between 
Table 1. Rock properties of the different bodies used in the model. Heat production and thermal conductivity values are taken from Morgan (1984) and Furlong and Chapman (1987).

\begin{tabular}{lccc}
\hline & Density $\left(\mathrm{kg} \mathrm{m}^{-3}\right)$ & $\begin{array}{c}\text { Heat production } \\
\left.(\mu \mathrm{W} \mathrm{m})^{-3}\right)\end{array}$ & $\begin{array}{c}\text { Thermal conductivity } \\
\left(\mathrm{W} \mathrm{m}^{-1} \mathrm{~K}^{-1}\right)\end{array}$ \\
\hline Quaternary sediments & $2600-400 \mathrm{e}^{-z / 2}(z$ in $\mathrm{km})$ & 0.5 & 2 \\
Salt layer & 2100 & 0.1 & 6 \\
Siliciclastic sediments & 2450 & 0.1 & 2 \\
Carbonates & 2550 & 0.5 & 2 \\
Upper continental crust & 2750 & 2 & 2.5 \\
Lower continental crust & 2900 & 0.2 & 2.5 \\
Lithospheric mantle & T-dependent, see text & 0.02 & 3.4 \\
\hline
\end{tabular}

NW Saida-Tyr-Platform (34.8/33.9-35.25/33.4) SE
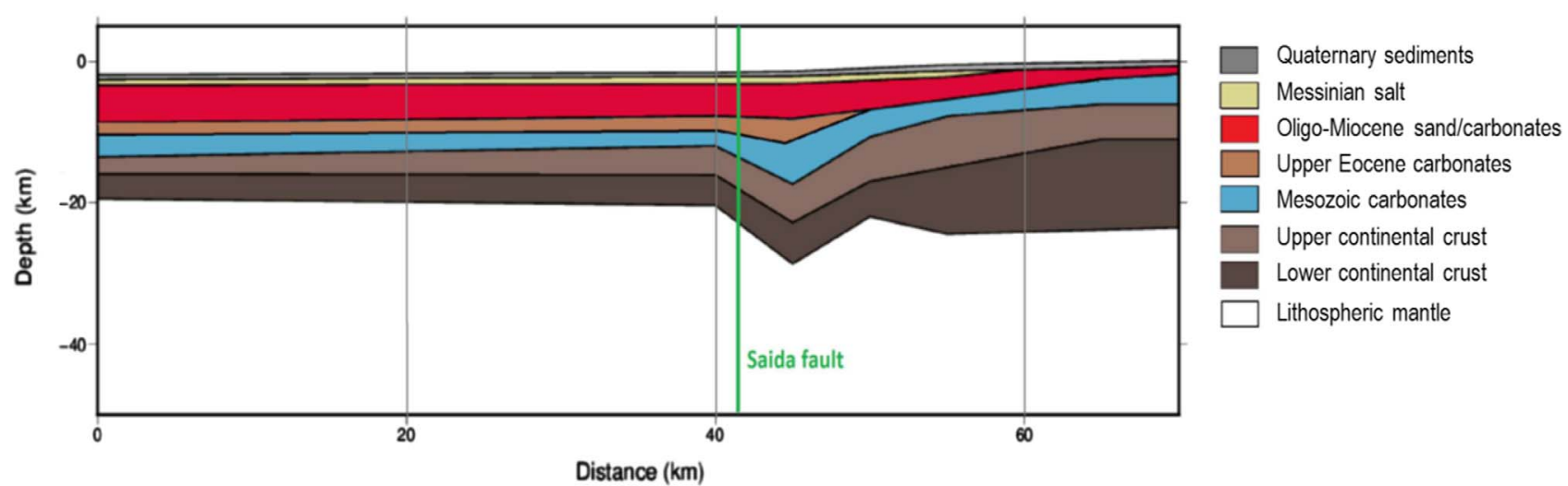

Fig. 8. Crustal model of profile STP based on gravity data (for the location of the profile refer to Fig. 7A and 7B).

the geometry of this fault, that of its extension onshore (the Damour fault), and the other ENE-WSW dextral strike-slip cross-cutting the northern Levant margin, which are still active at present day based on seabed deformation. The large vertical displacement observed on Saida fault could point to a previous normal event prior to the strike-slip movement.

West of the STP, two deep, vertical N-E trending structures are observed displacing the Senonian unconformity horizon by about $2 \mathrm{~km}$ (Fig. 10). These structures are about $15 \mathrm{~km}$ long each. They appear to deform the base Messinian horizon (Ghalayini et al., 2018; Fig. 10). Poor seismic imaging within the anticline's core makes it challenging to accurately determine the geometry of the older Tertiary units. The overall shape, however, resembles that of a positive flower structure. In addition, the steep and vertical dip of the fault indicates that it is most likely a strike-slip fault with a strong transpressive component.

East of the STP and closer to the coast, an array of normal faults has been identified and interpreted in the Mesozoic units (Figs. 9 and 11). These faults are oriented ENE-WSW to ESE-WNW and are mainly localized in the Cretaceous strata (Fig. 11). Few faults are observed to cross-cut the base Cretaceous and die out in the Upper
Jurassic units, and one fault reaches the Triassic. They show an overall normal displacement of about $200 \mathrm{~m}$ and are dipping either to the north or south. No thickness variation is observed across fault planes. The Upper Cretaceous unit is capped by an erosional unconformity truncating all units. The Pliocene is deposited uniformly over the Cretaceous and is not deformed by any normal fault. The faults do not extend to the Pliocene and are also capped by the same unconformity.

In the Adloun well, the Lower Cretaceous clastics have an overall thickness of $150 \mathrm{~m}$; whereas they are believed to be $2 \mathrm{~km}$ thick, based on seismic interpretation, in the deep basin west of the transpressive anticlines (Fig. 10). The overlying units consist of the Mid to Upper Cretaceous shallow water carbonates. At the western edge of the Jurassic and Cretaceous platforms, the wedge-shaped geometries and the associated westward variation of seismic facies may be interpreted to indicate the presence of talus deposits originating from the carbonate platform in the east (Fig. 10; Hawie et al., 2014; Ghalayini et al., 2018). Pinnacle-shaped geometries locally overly the Mesozoic unit and might correspond to local build-ups or isolated carbonate mounds. Along the STP, the Oligo-Miocene unit has a maximum reach of about 15-30 km away from the present coastline 


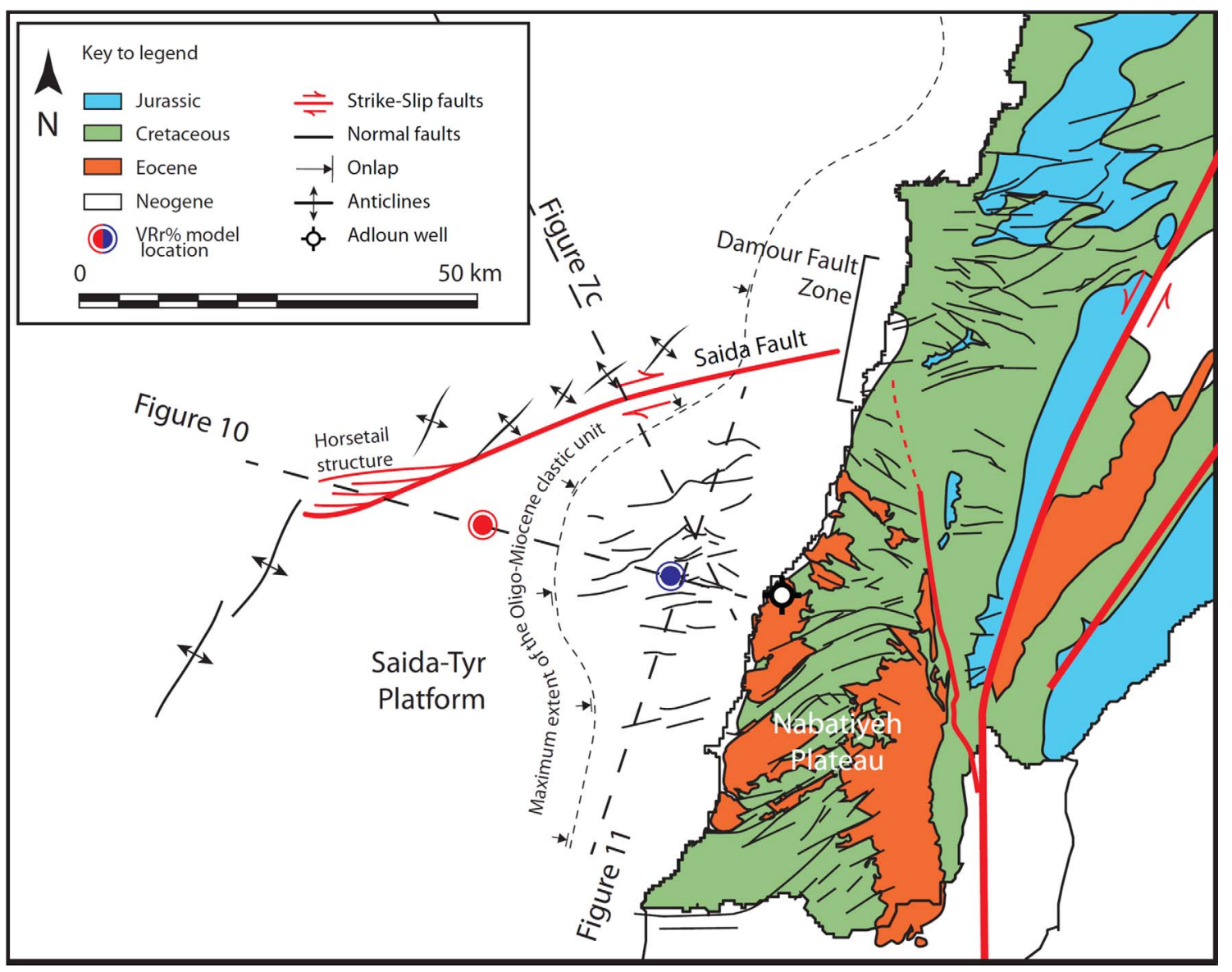

Fig. 9. Map showing the structures of the Levant margin south of Lebanon along both the STP and the Nabatiyeh Plateau. Check Figure 1 for location. Modified from Ghalayini et al. (2018). Red and blue dots mark the location of 1D burial model extracts presented in Figure 15 representing maturation trend for the distal and proximal STP, respectively.

and consists of siliciclastic sediments (Figs. 9 and 10). At its eastern termination, the Oligo-Miocene is observed to thin and pinch-out laterally on the Mesozoic units (Fig. 10).

\section{Discussion}

\subsection{Relationship of the Levant eastern margin and the Palmyra Basin}

Several points of similarities are found between the Palmyra Basin and the adjacent Levant Basin in general, and its eastern margin in particular. Both basins were formed during multiple phases of rifting in the Permo-Triassic times (e.g. Brew et al., 2001; Nader, 2014). The westward continental crust thinning from the Syrian hinterland to offshore Lebanon, may indicate continuity from the Palmyra through the Levant Basins with no abrupt crustal variation (e.g. Khair et al., 1993; Brew et al., 2001; Inati et al., 2016). Moreover, the stretching of the crust - as a result of the known rifting pulses - characterizes surviving fragments of the Neo-Tethys ocean passive margin, where the thick continental crust thins out. The rest of the Neo-Tethys Ocean has been consumed during the various tectonic regimes, such as the subduction and collision in northern Arabia and north Africa (e.g. Frizon De Lamotte et al., 2011).

The Levant and Palmyra Basins were deformed differently upon the collision of the Afro-Arabian and Eurasian plates in the Cretaceous, and this is likely related to their distinct crustal nature. While the Palmyra Basin and the margin of the Levant Basin, floored with thick continental crust, inverted to form the Syrian Arc structures - and locally the Palmyrides, the Levant Basin experienced further subsidence. For example, the structural style of the N-E Palmyrides and the Northern Mount Lebanon, the SW Palmyrides and the Southern Mount Lebanon are comparable. Both are believed to be dominated by thin- and thick-skinned tectonics, respectively (Chaimov et al., 1992; Searle, 1994; Butler et al., 1998; Brew et al., 2001; Nader, 2011). The initial uplift of Mount Lebanon, bordering the Levant Basin, is believed to have taken place in the Early Miocene (Dubertret, 1972; Beydoun, 1999; Homberg et al., 2010; Nader, 2014; Ghalayini et al., 2017b) coeval with the most prominent uplift time of the Palmyrides (Brew et al., 2001; Sawaf et al., 2001; Barrier et al., 2014).

The Saida, Damour and Jhar faults (Fig. 1) are delimiting crustal blocks, and consist of old normal faults 


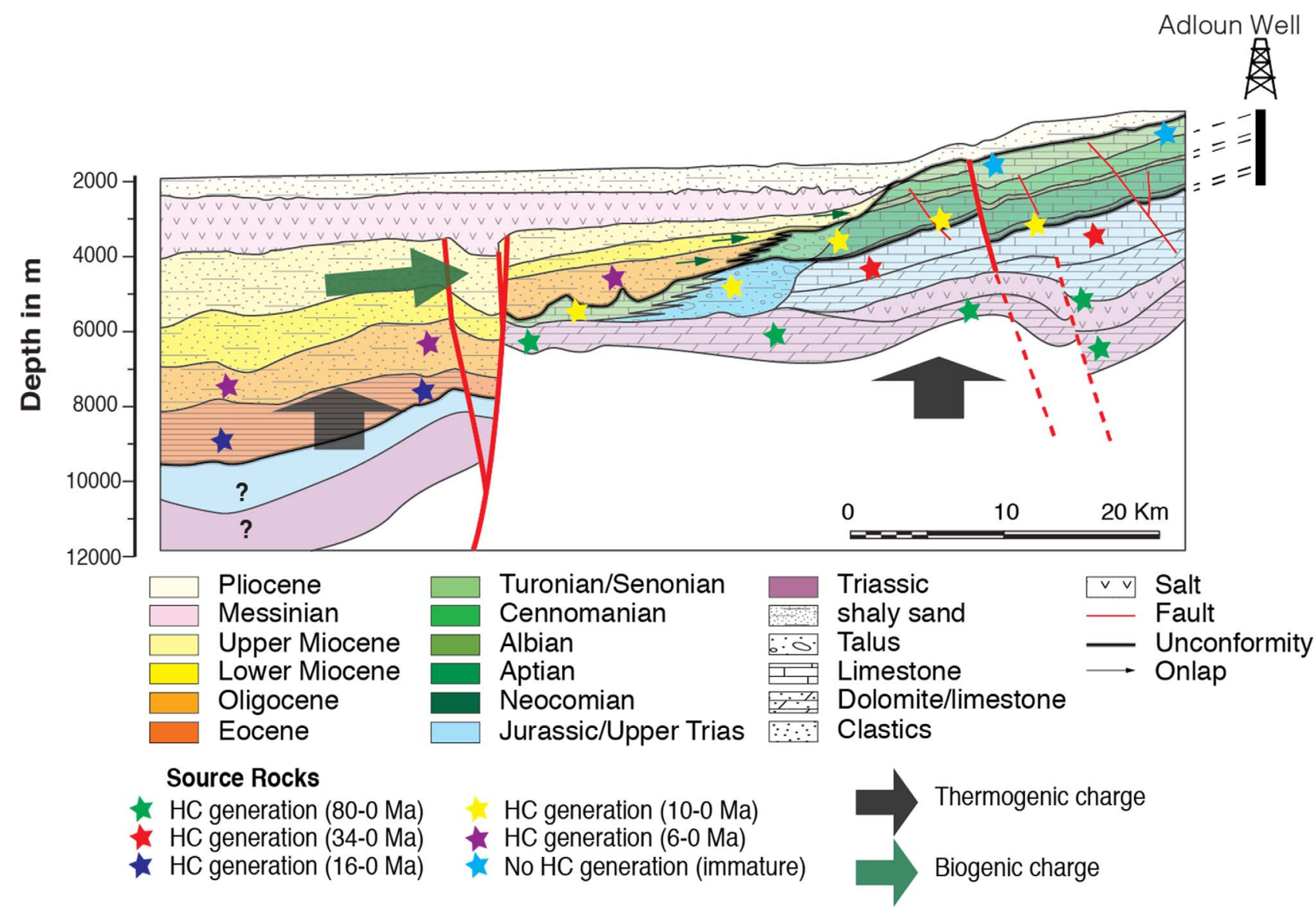

Fig. 10. Seismic line and its interpretation showing the tectono-stratigraphy of the southern margin offshore Lebanon. The line was tied to the Adloun-1 well onshore (see Fig. 9 for location). Modified from Ghalayini et al. (2018).

which currently are active as dextral strike-slip faults and exhibit seismic activity. Therefore, it is very likely that they are genetically related (Walley, 1998; Ghalayini et al., 2017b), and were differently affected by the Levant Fracture System (LFS). While the Saida fault is located about $80 \mathrm{~km}$ south of the Jhar fault at present day, it is very likely that this separation is due to the passage of the LFS.

Both, the Levant margin and the Palmyra Basin, witnessed similar tectonic events with rifting and inversion, followed by strike-slip tectonics in the Late Miocene. It is likely that the pre-existing structures played an important role in affecting the style of deformation along the central Levant margin, in a similar way to the Palmyrides. Based on the similarities listed above, it is very likely that the Levant margin, constitutes in fact the westward termination of the Palmyra Basin.

\subsection{Implications of crustal models on geodynamics}

The crustal thickness is progressively attenuated and varies from about $35 \mathrm{~km}$ in Syria to $<9 \mathrm{~km}$ under the Levant Basin (Inati et al., 2016). Close to the present coastline, the Levant margin has a crustal thickness of about
$15 \mathrm{~km}$, and a Moho at about $28 \mathrm{~km}$ is expected under the STP (Inati et al., 2018). Here, the thickness of the sedimentary package is about $6 \mathrm{~km}$, considerably thinner than the one in the deep basin (ca. $\sim 12 \mathrm{~km}$ ). Thus, the STP appears to relate to the continental section that was less stretched than the surrounding offshore. A key element in this framework is the Saida fault, which is believed to be a crustal feature (deeply rooted, Fig. 10) and a probable extension of the Jhar fault in Syria (Ghalayini et al., 2017b). Brew et al. (2001) suggested that the Jhar fault crossing through Palmyra, is an old pre-Cambrian suture zone that separates two blocks with different crustal structures. Therefore, its westward extension offshore Lebanon, the Saida fault, might also be an old suture zone. The Mesozoic rifting only accentuated the relatively weak zone along Saida fault, while the STP remained a fragment largely unaffected by stretching.

The STP is an extension of the continent into the basin, the rheological properties of its crust are similar to the ones of the continental crust onshore. Therefore, the interface between the thick continental crust under STP and the thinned continental crust of the Levant Basin marks a zone of rheological contrast in which deformation is preferentially localized. A similar zone has been previously referred 

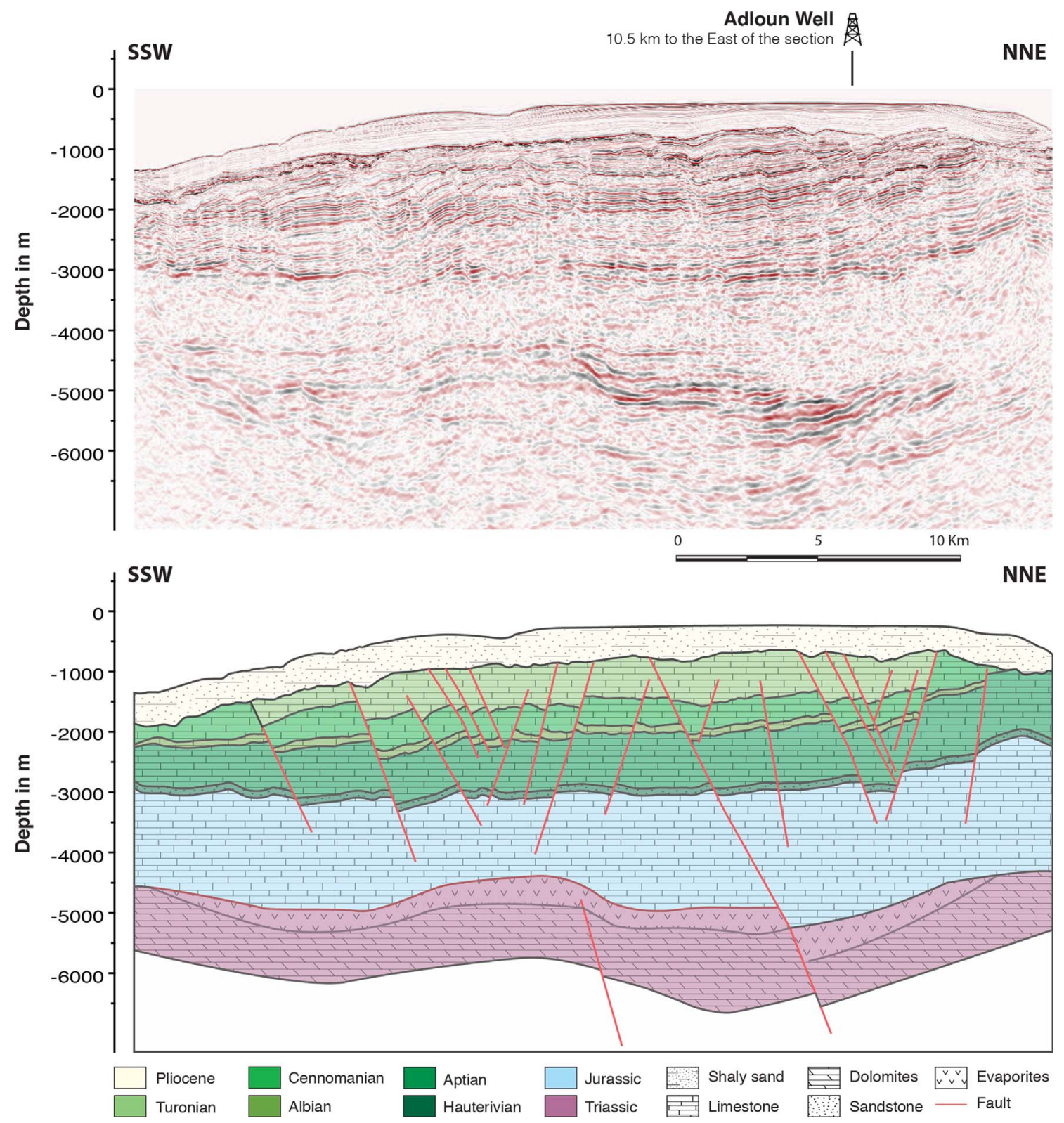

Fig. 11. Seismic line showing the normal fault array interpreted in the Saida-Tyr Platform. See Figure 9 for location.

to as the hinge zone, a narrow area parallel to the coast extending from Sinai in the south to Syria in the north, bending eastward in Lebanon (Fig. 12), and representing the continental-thinned versus continental crust interface (Steckler et al., 1988).

The propagation of the Red Sea rift into the Aqaba segment instead of the Gulf Suez segment was due to such rheological contrasts at the continental-oceanic interface (Steckler and Brink, 1986). The majority of this relative movement between the plates have shifted eastward to the Gulf of Aqaba formed along a zone of minimum strength, creating a new plate boundary between Arabia and Africa. In the Early Miocene, this movement has been transferred into the eastern Mediterranean forming the LFS which accommodated deformation in a strike-slip motion parallel to the margin (Freund et al., 1970). The location of the LFS is therefore a preferential one, being parallel to the Levant's margin, and controlled by the interface (or boundary) between the thinned continental and continental crust.

The evolution and propagation of the LFS from Aqaba to the Taurus is most likely affected by local lithospheric strength variations along its path. Right-stepping faults in the Dead Sea segment are caused by the passage of the presence of the Azraq-Sirhan graben which is associated with crustal thickness variations and therefore affecting the northward propagation of the LFS (Segev et al., 2014). Similarly, the Palmyra Basin is an intra-plate rift basin which is associated with a specific crustal setting (Brew et al., 2001). The interaction between the Palmyra Basin 
and the northward propagating LFS in Lebanon should have a similar effect on the geometry and configuration of the plate boundary, especially that deeper structures are expected to have been in place prior to the LFS propagation (Beydoun, 1999; Nader, 2011; Ghalayini et al., 2014). This explains how the LFS bends rightward in Lebanon by reactivating and amplifying existing structures, such as the Yammouneh and Serghaya faults, rather than creating new ones (Ghalayini et al., 2017a).

The crustal interface - discussed above - is located further westward along the STP boundary with the deeper Levant Basin (Fig. 12). Here, characteristic S-N trending anticlines mark the westward limit of STP. Notice that no similar structures are found further west in the Levant Basin. Similar structures are found further to the north, marking the hinge zone limit almost parallel to the LFS (Fig. 12). In fact, all anticlinal deformations documented in offshore Lebanon (Ghalayini et al., 2014) are located within this hinge zone and all the E-W trending dextral strike-slip faulting and associated deformation are contained east of this crustal interface. This new delineation of the hinge zone explains several geological observations, such as: (i) why E-W strike-slip faulting does not extend further west in the deep basin; (ii) why anticlines offshore Beirut are closer to the coast than the anticlines further south; and (iii) why deformation associated with the LFS is close to the margin as there is no evidence for LFS deformation further west. Even though the LFS is a large structure and is likely to have a strong effect on the surrounding basins, the containment of deformation between the plate boundary and the crustal interface could only indicate that the effect of the LFS is only present in areas having a continental crust while areas having thinner crusts could not accommodate such deformation, due to distinct rheological properties.

\subsection{Structural and stratigraphic characteristics of the Saida-Tyr Platform (STP)}

The STP consists of relatively uplifted Mesozoic strata with thin Cenozoic cover, contrasted to the thicker Cenozoic filling in the adjacent Levant Basin. The Saida fault acts as a major structure that affects the crustal and the tectono-stratigraphic architecture of the basin, and could be an inherited pre-Cambrian suture zone as discussed above. Similar ENE trending dextral strike-slip faults are documented along the eastern and southern Levant margin (Ghalayini et al., 2014; Segev et al., 2018). They are believed to have formed in the Early Cretaceous as normal faults (Homberg et al., 2009) and were reactivated in the Late Miocene to present day as dextral strike-slip faults (Ghalayini et al., 2014). It is worth noting that such structures are not believed to be linked to the Permo-Triassic extension event, since syn-rift normal faults of Triassic age are documented offshore and are oriented NNW-SSE (Ghalayini et al., 2018). Similar Triassic extensional faults are not documented onshore Lebanon to date because the Triassic is not outcropping. Since these faults are seated in syn-rift Triassic units, the post-rift shallow-marine carbonate succession visible onshore Lebanon is unlikely

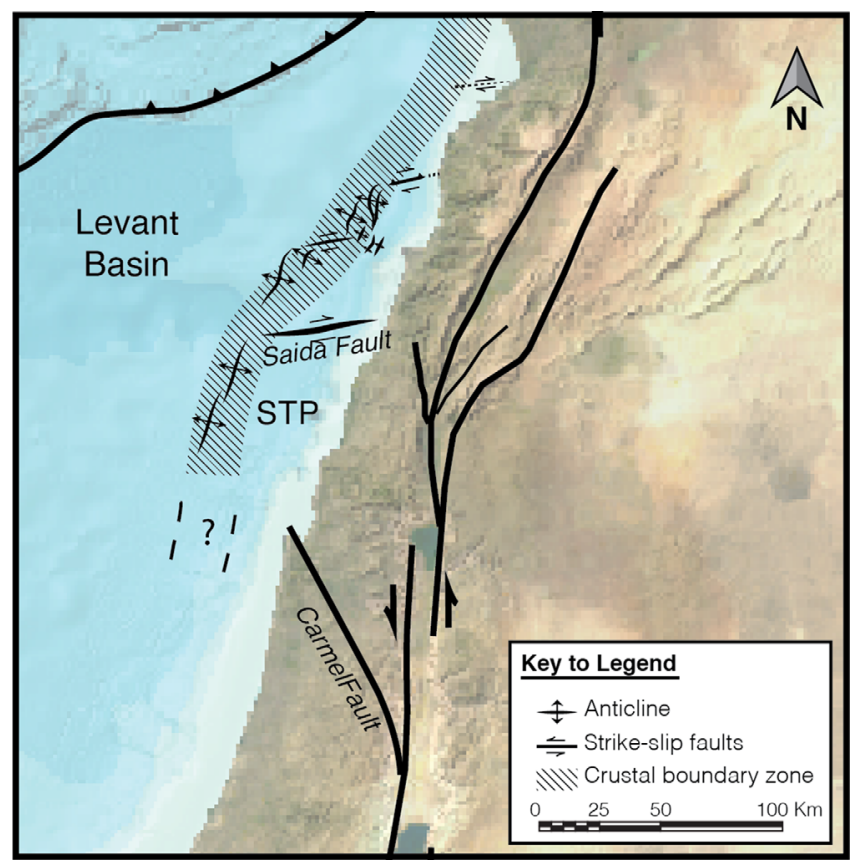

Fig. 12. Map showing the STP (Saida-Tyr Platform) as a key structure acting on the propagation of the Levant Fracture System. The dashed zone corresponds to the "hinge zone" after Steckler and Brink (1986) and its suggested extension in the Lebanese domain. Note the presence of anticlines that are located at the boundary between the continental crust to the east, and the thinned continental crust of the Levant Basin to the west.

to contain such structures. The difference in strike between the Triassic and Early Cretaceous faults points to a counter-clockwise rotation of the Levant margin during the Jurassic and localized subsidence and extension during the Early Cretaceous which has affected the entire Levant margin (Homberg et al., 2009).

Early Cretaceous extension and subsidence were accompanied by abundant fluvio-deltaic sediment deposition marking the return to emergent conditions (more than $300 \mathrm{~m}$ of such siliciclastic sediments were deposited in southern Lebanon; Dubertret 1972; Walley, 1998). Depositional patterns identified in the Jezzine region (north of Tyr-Nabatiyeh Plateau, southern Lebanon) point to a NE-SW sediment transport orientation, alluding to a potential structural control on sediment pathways, mainly by the E-W latitudinal normal faults. The identification of the Lower Cretaceous clastic units (i.e. Chouf Sandstone) along the STP, is also performed through well correlation and facies interpretation in seismic data. East of STP, a $150 \mathrm{~m}$ thick Chouf sandstone unit is documented in the Adloun- 1 well and it is attested that it extends offshore (Ghalayini et al., 2018). It is very possible that the Chouf Formation becomes thicker to the west (up to $2 \mathrm{~km}$ thick based on seismic interpretation), as there is a larger accommodation space. Therefore, STP, or the Levant margin in general, could be a bypass in which the Lower Cretaceous clastics become thicker in the basin. This also implies that possible clastic units are also found elsewhere 
in the STP, such as below the Lower Cretaceous carbonate mounds.

A return to marine conditions prevailed in the Early Cretaceous with cliff forming units (Aptian) overlain by a terrigenous rich Albian sedimentation. Such types of Lower Cretaceous shallow carbonate rock units might include important reservoirs. Ghalayini et al. (2018) showed that such units are expected in the STP by correlation with well data onshore. In addition, mound-shaped geometries of Early Cretaceous age are documented in an area of $200 \mathrm{~km}^{2}$ in the STP and could be of reefal origin, pointing to a wide platform development in a shallow water environment along the southern Levant margin at the time (Hawie et al., 2014). In the Late Cretaceous, an extensive marine domain prevailed along Lebanon Cenomanian-Turonian with extensive development of rudist platforms (Hawie et al., 2014). Associated sedimentary facies variations have been attested onshore Lebanon pointing to deeper depositional settings towards central and southern Lebanon. Hiatuses have been dated and correlated to major geodynamic events linked to the subduction and collision of the AfroArabian Plate with Eurasia (i.e., Late Turonian to Late Santonian, Late Maastrichtian to Early Paleocene, Early/ Middle Eocene to Middle Miocene) (Sharland et al., 2001; Hawie et al., 2014).

The western boundary of the STP is dominated by Late Miocene transpressive anticlines. They do not affect the Cenozoic sedimentation but clearly mark a sharp boundary within the Mesozoic units. The Karish field, $5 \mathrm{~km}$ south of the STP anticlines documented in this study, is also classified as a transpressive structure with a positive flower geometry (www.energean.com). The anticlines located offshore Beirut and Byblos are believed to exhibit thin-skinned deformation with detachment within the Eocene unit (Ghalayini et al., 2014, 2018). Other anticlines in the farther distal basin most probably consist of roll-over folds in the hanging wall of tilted fault blocks. Therefore, transpression is only located at the western boundary of the STP and the structures affected are deep and crustal. Prior to the transpression, extensional normal faults are believed to have been present in the same location bordering the STP that were inverted during the Late Miocene as positive flower structures (Hawie et al., 2014; Ghalayini et al., 2018). It is very likely that these structures are still active today, as evidenced by seafloor deformation on top of these anticlines. The continuous present-day activity is also supported for all the ENE trending dextral-strike faults along the margin (Ghalayini et al., 2014).

East of the STP, the Tyr-Nabatiyeh Plateau (TNP) dominates the shelf onshore southern Lebanon. It consists of a large platform mainly composed of a Cenomanian-Turonian succession with widespread Eocene nummulitic shoals. The TNP contains an array of WNW-ESE trending faults tens of kilometers long and having $>100 \mathrm{~m}$ vertical offset with no landscape expression (Butler et al., 1998). Sub-vertical and normal striae are documented on some fault planes, when outcropping, indicating a normal movement with little strike-slip component (Homberg et al., 2010). These faults show similarities with the faults found in northern Galilee (Israel; Ron et al., 1990). The normal fault arrays documented in this study in the Mesozoic units of the STP show remarkable similarities with the normal faults of the TNP. The former are ENE-WSW trending normal faults with also 100-200 $\mathrm{m}$ of displacement.

The age attributed to the faults of the Tyr-Nabatiyeh Plateau in the south of Lebanon is believed to be of Eocene age together with a suspected Late Cretaceous activity (Homberg et al., 2010). The lack of surface expressions and the limited outcrop exposures make it challenging to properly characterize these faults. It is very probable, however, that the faults in the STP are also of the same age as the one in the Tyr-Nabatiyeh Plateau knowing the large geometrical similarities between both fault sets. The hiatus between the Pliocene and Cenomanian units makes it difficult to prove the pre-Pliocene activity of these faults. Ron et al. (1990) suggest that the deformation in northern Galilee and southern Lebanon is still active at present day. The earthquake epicenter map (Fig. 1) shows earthquake clustering on the TNP while earthquakes are almost inexistent over the faults in the STP. This indicates that the faults in the TNP are currently active in contradiction with the faults in the STP which are probably inactive at present day. This could be related to the fact that the TNP is closer to the Yammouneh and the Roum faults and therefore more affected by deformation.

\subsection{Petroleum systems}

The oldest proven source rocks along the onshore eastern margin of the Levant Basin are encountered within the Triassic and Lower Jurassic continental to shallow marine rock succession penetrated by deep wells onshore Israel (Bein et al., 1984; Gardosh et al., 2008). The organic content of these source rocks is expected to increase towards the deeper and more marine paleograbens in Lebanon and to the west into the offshore Levant Basin. Middle Jurassic organic-rich limestone have been encountered in coastal wells in southern Israel within the Barnea Formation, which is argued to be the source of the oil in the Helez field onshore Israel (Bein and Soffer, 1987; Gardosh et al., 2008). Upper Jurassic Kimmeridgian source rock potential has been identified onshore Lebanon in lenses of shales with extremely high TOC $(\approx 50 \mathrm{wt} \%)$, moderate $\mathrm{HI}$ and low OI found within a cliff forming reefal limestone formation (Bou Daher et al., 2016).

Lower Cretaceous source rocks have been identified onshore Lebanon as coaly shales interbedded within the sandy Chouf Formation (Fig. 2). These coaly shales are characterized by a very variable TOC $(\approx 3 \mathrm{wt} \%$ up to $\approx 60 \mathrm{wt} \%$ ), and a low to moderate HI and OI rendering them a mostly gas prone source rock (Bou Daher et al., 2016). These Lower Cretaceous source rocks, however, seem to have a wide regional distribution as they are also reported within the Alam El Bueib Formation of the western desert, Egypt (Moretti et al., 2010). The Cenomanian succession onshore Lebanon has been proven to include source rocks with 1-3 wt\% TOC and extremely high HI, however, with thickness limited to only a few meters (Bou Daher et al., 2016). The Upper Cretaceous Campanian Maastrichtian source rocks (Fig. 2) seem to be the most 

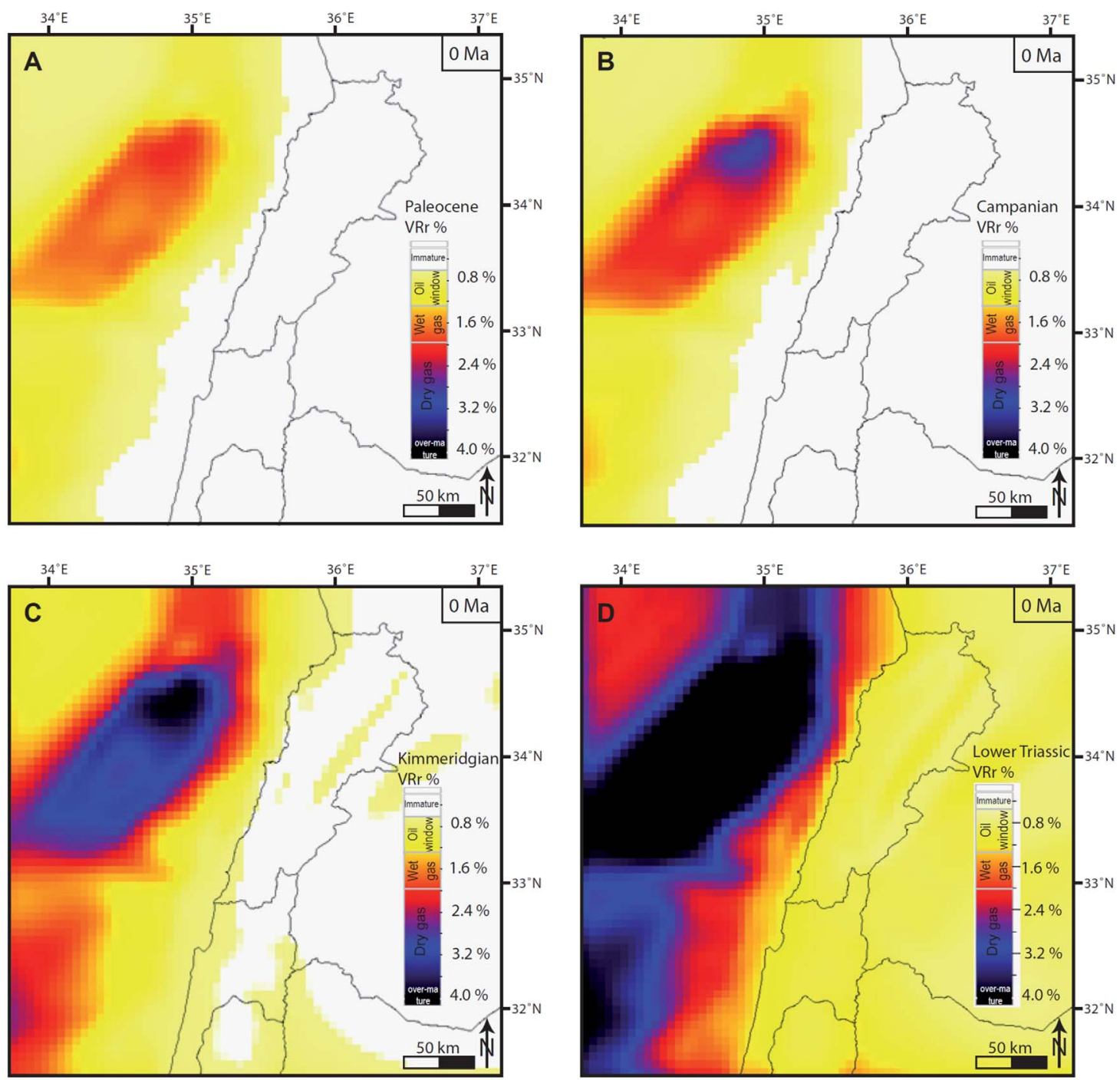

Fig. 13. Maps showing the modeled vitrinite reflectance (VRr\%) for key intervals at present day (from Bou Daher et al. 2016): (A) Paleocene; (B) Campanian; (C) Kimmeridgian; and (D) Lower Triassic.

prolific source rocks exposed onshore, along the eastern margin of the Levant Basin, and by far the most studied (Bein et al., 1990; Minster et al., 1992; Almogi-Labin et al., 1993, 2012; Ashckenazi-Polivoda et al., 2010, 2011; Schneider-Mor et al., 2012; Bou Daher et al., 2014, 2015). In Lebanon, the Campanian - Maastrichtian carbonates include around $150 \mathrm{~m}$ of excellent source rocks, with a TOC up to $12 \mathrm{wt} \%$ in south Lebanon, a HI up to $872 \mathrm{mg}$ $\mathrm{HC} / \mathrm{g}$ TOC, and classified as type II and type IIS source rock (Bou Daher et al., 2015, 2016). The Paleocene rock succession has been proven to include around $30 \mathrm{~m}$ of types II and III source rock in north Lebanon (Bou Daher et al., 2016).

With the exception of the Triassic to Middle Jurassic source rocks, all the above identified source rocks along the onshore eastern margin of the Levant Basin are immature (Fig. 13). However, thermal and burial history modeling revealed that the thermal maturity towards of these potential source rocks intervals gradually increase offshore due to differential burial during the Cenozoic (Bou Daher et al., 2016). According to the model presented by Bou Daher et al. (2016) the Permian-Triassic rock package in the offshore has entered the oil window during the Late Cretaceous, the gas window during the Eocene, and got overmature during the Late Miocene. The Upper JurassicLower Cretaceous rock package entered the oil window in the offshore basin during the Eocene, the gas window during the Late Miocene, and remains in the dry gas window today in most of the offshore Levant Basin (Figs. 10 and 13). The Upper Cretaceous-Eocene rock package has entered the oil window in the offshore Levant Basin during the Late Eocene, and the gas window in the deepest offshore realm during the Miocene (Figs. 10 and 13). The lower part of the Oligocene has reached the oil window during the very Late Miocene only in the deepest offshore basin. A big portion of the Oligo-Miocene succession remains 


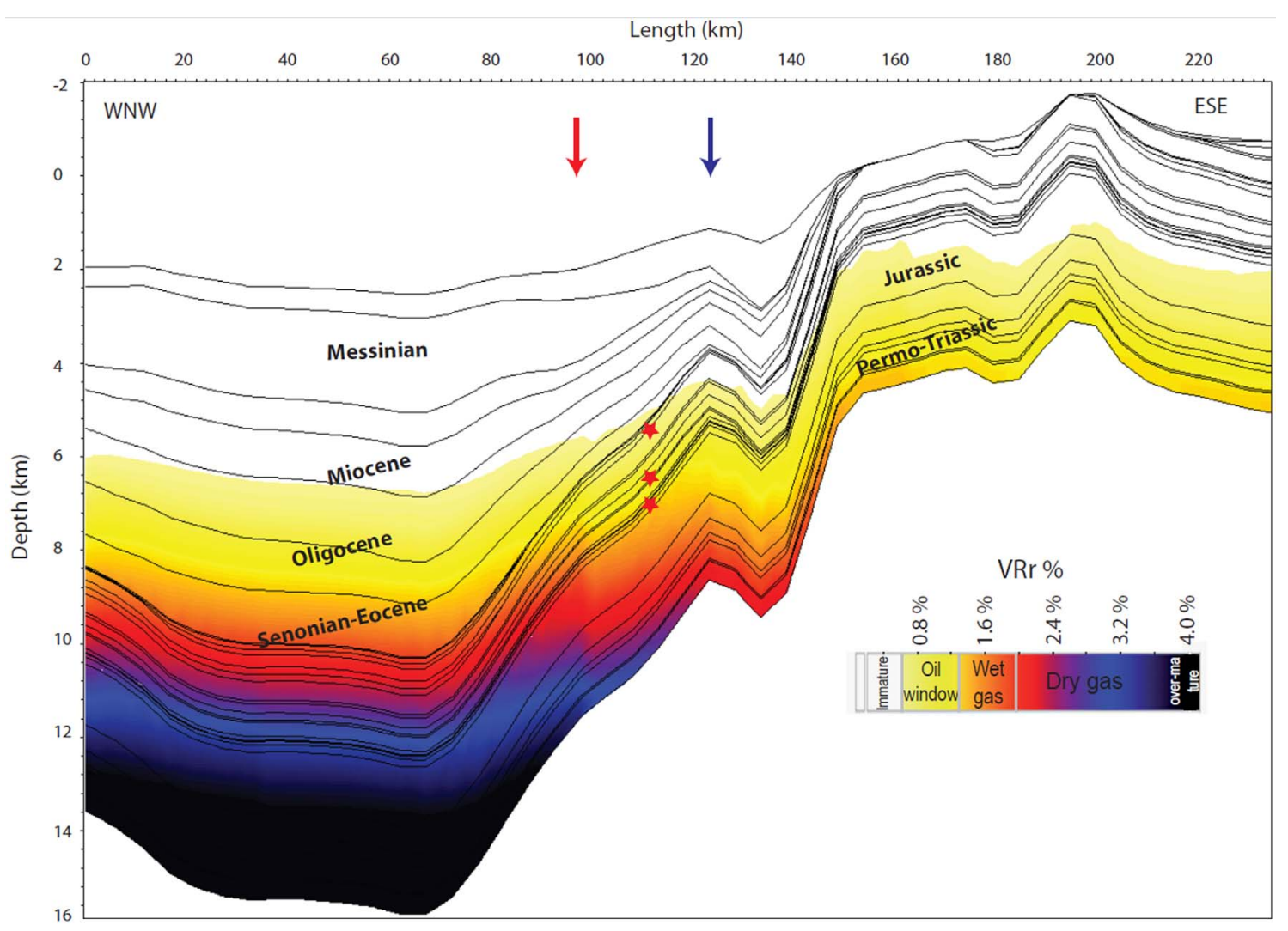

Fig. 14. Onshore-Offshore cross-section featuring the modeled vitrinite reflectance (VRr\%) with depth and the major stratigraphic intervals at present day (from Bou Daher et al., 2016). The location of this section is the same as that of Figure 10 with landward extension (shown in Fig. 9). The three stars represent the source rock intervals presented in Figure 15. Blue and red arrows represent the locations of the blue and red points in Figure 9 (indicating the proximal and distal locations for the 1D extracted vitrinite models.

immature and thus sits in the biogenic gas window (Figs. 10 and 13).

The offshore and onshore realms of the Levant Basin have different subsidence and burial histories that would suggest different potential petroleum systems (Nader, 2011). Hence, one can reflect on an overall Cenozoic petroleum system in the distal offshore and a Mesozoic petroleum system in the onshore (Bou Daher et al., 2016; Ghalayini et al., 2018). The STP shares elements with both realms, and thus, it can include both generalized petroleum systems. For example, the westernmost anticlinal structures of the STP (Figs. 9 and 10) might be charged by the Cenozoic biogenic gas system similar to the nearby structures offshore Israel and Cyprus. The eastern part of the STP is typical of the Levant margin and onshore systems (Fig. 11). Here, the Mesozoic succession includes several active source rock intervals, which were also supported by burial/thermal modeling (Figs. 10 and 14).

The distal/proximal characteristics of the STP are clearly observed on the modeled vitrinite reflectance across the STP (Figs. 13 and 14), and must be taken into consideration when assessing the related petroleum systems. Numerical modeling helps in proposing the timing of maturation of potential source rocks at different locations within the STP (Bou Daher et al., 2016). Figure 15 shows the maturation trends for three principal potential source rocks in proximal and distal locations of the STP. Accordingly, the Upper Jurassic and Lower Cretaceous source rocks (and partially the Campanian source rocks) appear to have reached the oil window in the STP (Figs. 14 and 15).

A particularly promising play is the combination of Upper Jurassic and Lower Cretaceous clastic and carbonate reservoirs sealed by overlying Cretaceous marls (Albian?) and sourced by matured Jurassic and Cretaceous type II and III source rocks (Fig. 15) (cf. Bou Daher et al., 2016). This play concept is similar to the proven play of the Mango field offshore Sinai (Gardosh et al., 2008; Nader, 2014; Bou Daher et al., 2016). A deeper play consisting of PermoTriassic source rocks, Triassic dolomite reservoirs sealed by middle Triassic evaporites could also be effective in the STP. This play concept is proven in the Palmyrides structures.

Traps are mostly structural and consist of the transpressive anticlines to the west that are Late Miocene in age. The pre-existing and reactivated faults within these anticlines may have permitted hydrocarbon migration to occur from deep Mesozoic thermogenic source rocks to shallower reservoirs. Potential stratigraphic traps may occur within the Mesozoic platform carbonates and Lower Cretaceous sand 


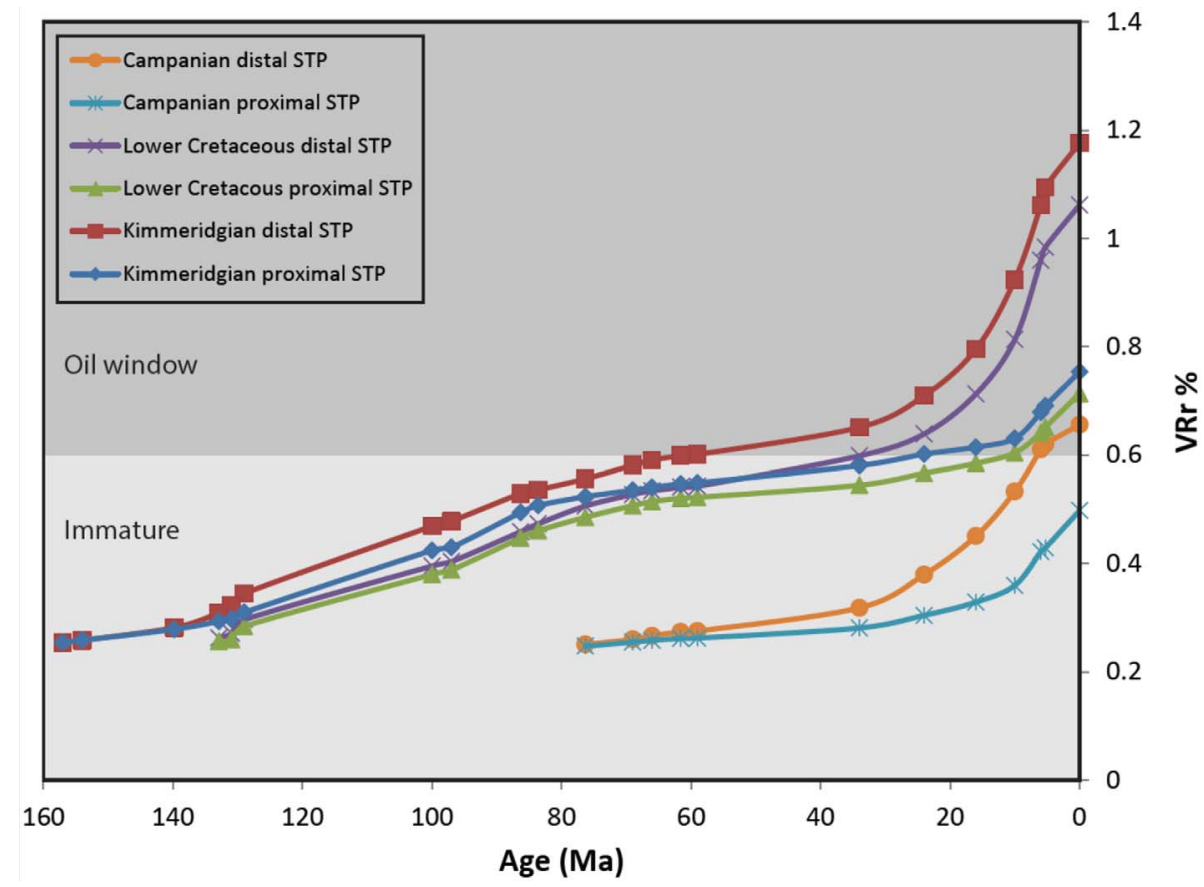

Fig. 15. Extracted modeled vitrinite reflectance (VRr\%) for key source rock intervals (Kimmeridgian, Lower Cretaceous, and Campanian) showing distinct maturation trends in proximal and distal STP (for location see Fig. 9).

sealed by Cretaceous carbonates. Other stratigraphic traps could include pinch-outs of Oligo-Miocene clastic units onto underlying Mesozoic strata (Fig. 10), and sealed by intraMiocene shales. Reservoirs on the western margin of the STP could still be charged through a combination of lateral migration from the deeper basin, where equivalent successions have reached higher thermal maturity, and from biogenic sources from within the Oligo-Miocene succession (Bou Daher et al., 2016). Such reservoirs very likely share similar properties as those documented in the Karish and the Tamar fields, hence their expected good quality. Potential source rocks, reservoirs and seals are indicated in Figure 2. Ghalayini et al. (2018) provide more detailed review on the petroleum systems on- and offshore Lebanon.

The improved understanding of the geology of the STP decreases the exploration risk for the Levant margin's plays. Some issues regarding the retention effectiveness, however, still remain a challenge to understand. The transpressive anticlines are most likely still active at present day which could result in higher permeability along fault plane and as a result reduce the hydrocarbon trapping effectiveness. In addition, gas chimneys and seabed pockmarks are observed in some locations over the STP indicating a potential seal-bypass across the Messinian and, or, deeper sealing units. As the Messinian is pinching out to the east and is absent on top of the Mesozoic units, deeper intra-formational seals must be present if hydrocarbons are to be trapped in the Mesozoic units. As discussed earlier, the Mesozoic unit documented onshore is expected to continue to the offshore realm. Nevertheless, the depositional environments deepen westward toward the basin and the reservoir/seal facies might be different. More research is still required to increase our understanding of the sedimentary facies expected offshore when considering the Mesozoic plays.

\section{Conclusion}

This contribution focuses the Saida-Tyr Platform (STP), an offshore area adjacent to the southern Lebanese coastline - part of the eastern margin of the Levant Basin, which is actually one of the licensed acreage for hydrocarbon exploration. A relatively extensive synthesis of previously (recently) published research work tackling crustal modeling, structural geology, stratigraphy and geochemistry helped in better integrating geo-data and shaping up the geological understanding of this area. In addition, a new crustal model and the interpretation of seismic reflection specifically on the STP led to the following conclusions:

- The Levant margin along the northwestern border of the Arabian Plate and the intra-plate Palmyra Basin (Syria, hinterland), witnessed similar tectonic events with rifting and inversion, followed by strike-slip tectonics in the Late Miocene.

- The STP is bordered by characteristic structural features and constitutes an extension of the Arabian continent into the Levant Basin, with similar crustal rheological properties.

- The westernmost limit of the STP consists of an interface of rheological contrast between the thick continental crust under STP and the thinned continental crust of the Levant Basin; in other words, it can be viewed as the extension of the "hinge zone", 
where major plate-scale deformations are preferentially localized.

- Similar S-N trending anticlines, almost parallel to the Levant Fracture Systems, offshore Lebanon illustrate the northward extension of the hinge zone and links it to the LFS establishment since the Late Miocene.

- Inherited structures were reactivated by younger tectonic events.

- In addition to the typical Levant Basin tectonostratigraphic elements with thick Cenozoic series, the STP is also characterized by relatively thick Mesozoic successions - similar to the surface exposed strata onshore Lebanon, highlighting the margin petroleum systems.

- In the STP, the Upper Jurassic/Lower Cretaceous clastics and carbonates are believed to provide potential reservoir plays that could have been charged by the deeper Mesozoic source rocks, and sealed by Cretaceous marly layers. The edge of the Cretaceous carbonate platforms (slope debris) and potential carbonate buildups are interesting to further investigate. While the western and northern anticlinal structures bordering the STP are excellent targets for Oligo-Miocene biogenic gas charging systems.

- The STP is an excellent example of the eastern margin of the Levant Basin offshore Lebanon, with a broad diversity of potential plays for hydrocarbon exploration; by integrating geodynamics, tectono-stratigraphic interpretations and petroleum systems analyses, such plays are better constrained and exploration risk lowered.

Acknowledgments. The authors would like to dedicate this work to the memory of Dr. Carla Müller who passed away in January 2018 and whose work and scientific contribution had a great impact on the current understanding of the geology of the EastMediterranean region and the support and promotion of young researchers. The two anonymous reviewers and the editorial office of $O G S T$ are also thanked for their comments and suggestions that certainly improved the content and form of this contribution.

\section{References}

Al Abdalla A., Barrier É., Matar A., Müller C. (2010) Late Cretaceous to Cenozoic tectonic evolution of the NW Arabian platform in NW Syria, in: Homberg C., Bachmann M. (eds), Evolution of the Levant margin and western Arabia platform since the Mesozoic, Geological Society Special Publications, London, 341, pp. 305-327, https://doi.org/10.1144/SP341.11.

Almogi-Labin A., Bein A., Sass E. (1993) Late Cretaceous upwelling system along the southern Tethys margin (Israel): interrelationship between productivity, bottomwater environments, and organic matter preservation, Paleoceanography $\mathbf{8}$, 671-690.

Almogi-Labin A., Ashckenazi-Polivoda S., Edelman-Furstenberg Y., Benjamini C. (2012) Anoxia-dysoxia at the sediment-water interface of the southern Tethys in the late Cretaceous: Mishash Formation, southern Israel, in: Altenbach A.V., Bernhard J.M., Seckbach J. (eds), Anoxia:
Evidence for Eukaryote Survival and Paleontological Strategies, Cellular Origin, Life in Extreme Habitats and Astrobiology, 21, Springer, pp. 553-572.

Ashckenazi-Polivoda S., Edelman-Furstenberg Y., AlmogiLabin A., Benjamini C. (2010) Characterization of lowest oxygen environments within ancient upwelling environments: benthic foraminifera assemblages, Palaeogeogr. Palaeoclimatol. Palaeoecol. 289, 134-144.

Ashckenazi-Polivoda S., Abramovich S., Almogi-Labin A., Schneider-Mor A., Feinstein S., Püttmann W., Berner Z. (2011) Paleoenvironments of the latest Cretaceous oil shale sequence, Southern Tethys, Israel, as an integral part of the prevailing upwelling system, Palaeogeogr. Palaeoclimatol. Palaeoecol. 305, 93-108.

Barrier É., Machhour L., Blaizot M. (2014) Petroleum systems of Syria, in: Marlow L., Kendall C., Yose L. (eds), Petroleum systems of the Tethyan region: AAPG Memoir, 106, pp. 335378.

Bein A., Soffer Z. (1987) Origin of oils in the Helez region, Israel: implications for exploration in the eastern Mediterranean, AAPG Bull. 71, 65-75.

Bein A., Feinstein S., Aizenshtat A., Weiler Y. (1984) Potential source rocks in Israel: a geochemical evaluation, Rep. 84/15, Israel Geological Survey GSI/17/84 and Oil Exploration (Investment) Ltd., $46 \mathrm{p}$.

Bein A., Almogi-Labin A., Sass E. (1990) Sulfur sinks and organic-carbon relationships in Cretaceous organic-rich carbonates: implications for evaluation of oxygen poor depositional-environments, Am. J. Sci. 290, 882-911.

Ben-Avraham Z., Ginzburg A., Makris J., Eppelbaum L. (2002) Crustal structure of the Levant Basin, eastern Mediterranean, Tectonophysics 346, 23-43.

Beydoun Z.R. (1977) Petroleum prospects of Lebanon: Reevaluation, AAPG Bull. 61, 43-64.

Beydoun Z.R. (1999) Evolution and development of the Levant (Dead Sea Rift) Transform System: A historical-chronological review of a structural controversy, in: Mac Niocaill C., Ryan P.D. (eds), Continental Tectonics, Geological Society Special Publications, London, pp. 239-255.

Bou Daher S., Nader F.H., Strauss H., Littke R. (2014) Depositional environment and source-rock characterisation of organic-matter rich Upper Turonian-Upper Campanian carbonates, Northern Lebanon, J. Petrol. Geol. 37, 1-20.

Bou Daher S., Nader F.H., Müller C., Littke R. (2015) Geochemical and petrographic characterization of Campanian-Lower Maastrichtian calcareous petroleum source rocks of Hasbayya, South Lebanon, Mar. Pet. Geol. 64, 304-323.

Bou Daher S., Ducros M., Michel P., Hawie N., Nader F.H., Littke R. (2016) 3D thermal history and maturity modelling of the Levant Basin and its eastern margin, offshore-onshore Lebanon, Arab. J. Geosci. 17, 3161.

Brew G.E., Barazangi M., Al-Maleh A.K., Sawaf T. (2001) Tectonic and geologic evolution of Syria, GeoArabia 6, 573-616.

Butler R.W.H., Spencer S., Griffiths H.M. (1998) The structural response to evolving plate kinematics during transpression: evolution of the Lebanese restraining bend of the Dead Sea Transform, in: Holdsworth R.E., Strachan R.A., Dewey J.F. (eds), Continental transpressional and transtensional tectonics, Geological Society Special Publications, London, pp. 81-106.

Chaimov T.A., Barazangi M., Al-Saad D., Sawaf T., Gebran A. (1992) Mesozoic and Cenozoic deformation inferred from seismic stratigraphy in the southwestern intracontinental Palmyride fold-thrust belt, Syria, GSA Bull. 104, 704-715. 
Chamot-Rooke N., Rabaute A., Kreemer C. (2005) Western Mediterranean Ridge mud belt correlates with active shear strain at the prism-backstop geological contact, Geology 33, $11,861-864$.

Collin P.Y., Mancinelli A., Chiocchini M., Mroueh M., Hamdan W., Higazi F. (2010) Middle and Upper Jurassic stratigraphy and sedimentary evolution of Lebanon (Levantine margin): palaeoenvironmental and geodynamic implications, in: Homberg C., Bachmann M. (eds), Evolution of the Levant margin and western Arabia platform since the Mesozoic, Geological Society Special Publications, London, 341, pp. 227-244, https://doi.org/10.1144/SP341.11.

Cordell L. (1973) Gravity analysis using an exponential densitydepth function- San Jacinto Graben, California, Geophysics 38, 4, 684-690. https://doi.org/10.1190/1.1440367.

Daeron M., Benedetti L., Tapponier P., Sursock A., Finkel R.C. (2004) Constraints on the post $\sim 25$-ka slip rate of the Yammoûneh fault (Lebanon) using in situ cosmogenic $36 \mathrm{Cl}$ dating of offset limestone-clast fans, Earth Planet. Sci. Lett. 227, 105-119, https://doi.org/10.1016/j.epsl.2004.07.014.

Dubertret L. (1955) Carte Géologique du Liban au 1/200000 avec notice explicative, République Libanaise, Ministère des Travaux Publiques, Beirut, p. 74.

Dubertret L. (1972) Sur la dislocation de l'ancienne plaque sialique Afrique Sinai peninsule arabique, Notes et mémoires sur le Moyen Orient 12, 227-243.

El-Isa Z., Mechie J., Prodehl C., Makris J., Rihm R. (1987) A crustal structure study of Jordan derived from seismic refraction data, Tectonophysics 138, 235-253, https://doi.org/10.1016/0040-1951(87)90042-4.

Freund R., Garfunkel Z., Zak I., Goldberg M., Weissbrod T., Derin B., Bender F., Wellings F.E., Girdler R.W. (1970) The Shear along the Dead Sea Rift [and Discussion], Philos. Trans. R. Soc. Lond A: Math. Phys. Eng. Sci. 267, 107-130, https://doi.org/10.1098/rsta.1970.0027.

Frizon De Lamotte D., Raulin C., Mouchot N., Christophe J., Daveau W., Blanpied C., Ringenbach J.C. (2011) The southernmost margin of the Tethys realm during the Mesozoic and Cenozoic: initial geometry and timing of the inversion processes, Tectonics 30, 1-22, https://doi.org/10.1029/ 2010 TC002691.

Furlong K., Chapman D.S. (1987) Crustal heterogeneities and the thermal structure of the continental crust, Geophys. Res. Lett. 14, 314-317.

Fürstenau J., Hawie N., Comstock J., Lowrey C.J. (2013) Aspects of the depositional history of the Levant Basin offshore Cyprus and Lebanon, Offshore Mediterranean Conference, Ravenna, Italy.

Gardosh M., Druckman Y., Buchbinder B., Rybakov M., Rybakov M. (2008) The Levant Basin Offshore Israel: stratigraphy, structure, tectonic evolution and implications for hydrocarbon exploration, Rep. GSI/17/84, Geophysical Institute of Israel and Oil Exploration (Investment) Ltd, 118 p.

Garfunkel Z. (1998) Constrains on the origin and history of the Eastern Mediterranean basin, Tectonophysics 298, 5-35, https://doi.org/10.1016/S0040-1951(98)00176-0.

Gedeon M. (1999) Structural analysis of latitudinal faults in the Mount Lebanon north of Beirut: their kinematic and their role in the tectonic evolution of Lebanon, MSc Thesis, American University of Beirut, Beirut, 245 p.

Ghalayini R., Daniel J.-M., Homberg C., Nader F.H., Comstock J.E. (2014) Impact of Cenozoic strike-slip tectonics on the evolution of the northern Levant Basin (offshore Lebanon), Tectonics 33, 2121-2142, https://doi.org/10.1002/ 2014TC003574.

Ghalayini R., Homberg C., Daniel J.M., Nader F.H. (2017a) Growth of layer-bound normal faults under a regional anisotropic stress field, in: Childs C., Holdsworth R.E., Jackson C.A.-L., Manzocchi T., Walsh J.J, Yielding G. (eds), The Geometry and Growth of Normal faults, Geological Society Special Publications, London, 439, pp. 57-78, https://doi.org/10.1144/SP439.13

Ghalayini R., Daniel J.M., Homberg C., Nader F.H., Darnault R., Mengus J., Barrier E. (2017b) The effect of the Palmyra trough and Mesozoic structures on the Levant margin and on the evolution of the Levant Restraining bend, in: Roure F., Amin A., Khomsi S., Al-Garni M.A.M. (eds), Lithosphere dynamics and sedimentary basins of the Arabian plate and surrounding areas, Springer, pp. 149-172.

Ghalayini R., Nader F.H., Bou Daher S., Hawie N., Chbat W.E. (2018) Petroleum systems of Lebanon: an update and review, J. Petrol. Geol. 41, 189-214.

Ginzburg A., Makris J., Fuchs K., Prodehl C., Kaminski W., Amitai U. (1979) A seismic study of the crust and upper mantle of the Jordan-Dead Sea Rift and their transition toward the Mediterranean Sea, J. Geophys. Res. Solid Earth 84, 1569-1582.

Ginzburg A., Ben-Avraham Z., Makris J., Hubral P., Rotstein Y. (1994) Crustal structure of northern Israel, Mar. Pet. Geol. 11, 501-506.

Gomez F., Meghraoui M., Darkal A.N., Sbeinati M.R., Darawcheh R., Tabet C., Khawlie M.R., Charabe M., Khair K., Barazangi M. (2001) Coseismic displacements along the Serghaya fault: an active branch of the Dead Sea fault system in Syria and Lebanon, J. Geol. Soc. 158, 405-408.

Gomez F., Khawlie M., Tabet C., Darkal A.N., Khair K., Barazangi M. (2006) Late Cenozoic uplift along the northern Dead Sea transform in Lebanon and Syria, Earth Planet. Sci. Lett. 241, 913-931, https://doi.org/10.1016/j.epsl.2005.10.029.

Grohmann S., Fietz S.W., Littke R., Bou Daher S., RomeroSarmiento M.F., Nader F.H., Baudin F. (2018) Source rock characterization of mesozoic to cenozoic organic matter rich marls and shales of the Eratosthenes Seamount, Eastern Mediterranean Sea, Oil Gas Sci. Technol. - Rev. IFP Energies nouvelles, this volume.

Hancock P.L., Atiya M.S. (1979) Tectonic significance of mesofracture systems associated with the Lebanese segment of the Dead Sea transform fault, J. Struct. Geol. 1, 143-153, https://doi.org/10.1016/0191-8141(79)90051-8.

Hawie N., Gorini C., Deschamps R., Nader F.H., Montadert L., Granjeon D., Baudin F. (2013) Tectono-stratigraphic evolution of the northern Levant Basin (offshore Lebanon), Mar. Pet. Geol. 48, 392-410, https://doi.org/10.1016/ j.marpetgeo.2013.08.004.

Hawie N., Deschamps R., Nader F.H., Gorini C., Müller C., Desmares D., Hoteit A., Granjeon D., Montadert L.And, Baudin F. (2014) Sedimentologic and stratigraphic evolution of northern Lebanon since the Late Cretaceous: implications on the Levant margin and basin, Arab. J. Geosci. 7, 4, 13231349, https://doi.org/10.1007/s12517-013-0914-5.

Hawie N., Deschamps R., et al. (2015) Multi-scale constraints of sediment source to sink systems in frontier basins: a forward stratigraphic modelling case study of the Levant region, Basin Res. 29, 1-28, https://doi.org/10.1111/bre.12156. 
Homberg C., Barrier É., Mroueh M., Hamdan W., Higazi F. (2009) Basin tectonics during the Early Cretaceous in the Levant margin, Lebanon, J. Geodyn. 47, 218-223. https://doi.org/10.1016/j.jog.2008.09.002.

Homberg C., Barrier É., Mroueh M., Müller C., Hamdan W., Higazi F. (2010) Tectonic evolution of the central Levant domain (Lebanon) since Mesozoic time, in: Homberg C., Bachmann M. (eds), Evolution of the Levant margin and western Arabia platform since the Mesozoic, Geological Society Special Publications, London, 341, pp. 245-268.

Inati L., Zeyen H., Nader F.H., Adelinet M., Sursock A., Elie M., Roure F. (2016) Lithospheric architecture of the Levant Basin (Eastern Mediterranean region): A 2D modeling approach, Tectonophysics 693, 143-156. https://doi.org/10.1016/ j.tecto.2016.10.030.

Inati L., Lecomte J.C., Zeyen H., Nader F.H., Adelinet M., Elie M., Sursock A. (2018) Crustal configuration in the northern Levant basin based on seismic interpretation and numerical modeling, Mar. Pet. Geol. 93, 182-204.

Khair K., Khawlie M., Haddad F., Barazangi M., Seber D., Chaimov T.A. (1993) Bouguer gravity and crustal structure of the Dead Sea transform fault and adjacent mountain belts in Lebanon, Geology 21, 739-742.

Lachenbruch A.H., Morgan P. (1990) Continental extension, magmatism and elevation: Formal relations and rules of thumb, Tectonophysics 174, 39-62.

Lachenbruch A.H., Sass J.H. (1977) Heat flow in the United States and the thermal regime of the crust, in: Heacoco J.G., Keller G.V., Oliver J.E., Simmons G. (eds), The Earth's Crust, Geophysical Monograph Series, 20, AGU, Washington DC, pp. 626-675.

Makris J., Ben-Avraham Z., Behle A., Ginzburg A., Giese A., Steinmetz I.. Whitmarsh R.B., Eleftheriou S. (1983) Seismic refraction profiles between Cyprus and Israel and their interpretation, Geophys. J. Int. 75, 575-591.

Minster T., Nathan Y., Ravh A. (1992) Carbon and sulfur relationships in marine Senonian organic-rich, iron-poor sediments from Israel e a case study, Chem. Geol. 97, 145-161.

Mitchum R.M. Jr. (1977) Seismic stratigraphy and global changes of sea level, part 11: glossary of terms used in seismic stratigraphy, in: Payton C.E. (ed.), Seismic Stratigraphy Application to Hydrocarbon Exploration, American Association of Petroleum Geologists Memoir, 26, pp. 205-212.

Moretti I., Kerdraon Y., Rodrigo G., Huerta F., Griso J.J., Sami M., Said M., Ali H. (2010) South Alamein petroleum system (Western Desert, Egypt), Petrol. Geosci. 16, 121-132.

Morgan P. (1984) The thermal structure and thermal evolution of the continental lithosphere, Phys. Chem. Earth 15, 107-193.

Müller C., Hihazi F., Hamdan W., Mroueh M. (2010) Revised stratigraphy of the Upper Cretaceous and Cenozoic series of Lebanon based on nannofossils, Geological Society, London, Special Publications, 341, pp. 287-303.

Nader F.H. (2011) The petroleum prospectivity of Lebanon: an overview, J. Petrol. Geol. 34, 135-156.

Nader F.H. (2014) Insights into the petroleum prospectivity of Lebanon, in: Marlow L., Kendall C.C.G., Yose L.A. (eds), Petroleum systems of the Tethyan region. AAPG Memoir 106, pp. $241-278$.

Nader F.H., Browning-Stamp P., Lecomte J.C. (2016) Geological intepretation of $2 \mathrm{D}$ seismic reflection profiles onshore Lebanon: implications for petroleum exploration, J. Petrol. Geol. 39, 333-356.
Netzeband G., Gohl K., Hübscher C., Ben-Avraham Z., Dehghani G.A., Gajewski D., Liersch P. (2006) The Levantine Basin - crustal structure and origin, Tectonophysics 418, 167-188, https://doi.org/10.1016/j.tecto.2006.01.001.

Papadimitriou N., Deschamps R., Symeou V., Souque C., Gorini C., Nader F.H., Blanpied C. (2018a) The tectonostratigraphic evolution of Cenozoic basins of the Northern Tethys: The Northern margin of the Levant Basin, Oil Gas Sci. Technol. Rev. IFP Energies nouvelles, this volume.

Papadimitriou N., Gorini C., Nader F.H., Deschamps R., Symeou V., Lecomte J.C. (2018b) Tectono-stratigraphic evolution of the western margin of the Levant Basin (offshore Cyprus), Mar. Pet. Geol. 91, 683-705, https://doi.org/ 10.1016/j.marpetgeo.2018.02.006.

Quennell A.M. (1958) The Structural and Geomorphic Evolution of the Dead Sea Rift, Q. J. Geol. Soc. 114, 1-24. https://doi.org/10.1144/gsjgs.114.1.0001.

Renouard G. (1955) Oil prospects of Lebanon, AAPG Bull. 39, 2125-2169.

Roksandi'c M.M. (1978) Seismic facies analysis concepts, Geophys. Prospect. 26, 383-398.

Ron H., Nur A., Eyal Y. (1990) Multiple strike-slip fault sets: a case study from the Dead Sea Transform, Tectonics 9, 14211431.

Saint-Marc P. (1975) Etude stratigraphique et micropaleontologique de l'Albien, du Cenomanien et du Turonien du Liban, in Notes et Memoires sur le Moyen-Orient, Museum national d'histoire naturelle, Paris, Tome XIII, 233 p.

Sangree J.B., Widmier J.M. (1977) Seismic interpretation of clastic depositional facies, in: Payton C.E. (ed.), Seismic Stratigraphy - Applications to Hydrocarbon Exploration, AAPG Memoirs 26, pp. 165-184.

Sawaf T., Brew G.E., Litak R.K., Barazangi M. (2001) Geologic evolution of the intraplate palmyride basin and euphrates fault system syria, in: Ziegler P.A., Cavazza W., Robertson A.H.F., Crasquin-Soleau S. (eds), Peri-Tethys Memoir 6: Peri-Tethyan rift/Wrench basins and passive margins, Memoire du Museum National D'histoire Naturelle, Paris, pp. 441-467.

Schneider-Mor A., Alsenz H., Ashckenazi-Polivoda S., Illner P., Abramovich S., Feinstein S., Almogi-Labin A., Berner Z., Püttmann W. (2012) Paleoceanographic reconstruction of the late Cretaceous oil shale of the Negev, Israel: integration of geochemical, and stable isotope records of the organic matter, Palaeogeogr. Palaeoclimatol. Palaeoecol. 319-320, 46-57.

Searle M.P. (1994) Structure of the intraplate eastern Palmyride fold belt, Syria, Geol. Soc. Am. Bull. 106, 1332-1350, https://doi.org/10.1130/0016-7606(1994)106<1332.

Searle M.P., Chung S.-L., Lo C.-H. (2010) Geological offsets and age constraints along the northern Dead Sea fault, Syria, J. Geol. Soc. 167, 1001-1008, https://doi.org/10.1144/001676492010-009.

Segev A., Rybakov M., Lyakhovsky V., Hofstetter A., Tibor G., Goldshmidt V., Ben-Avraham Z. (2006) The structure, isostasy and gravity field of the Levant continental margin and the southeast Mediterranean area, Tectonophysics 425, 137-157. https://doi.org/10.1016/j.tecto.2006.07.010.

Segev A., Lyakhovsky V., Weinberger R. (2014) Continental transform-rift interaction adjacent to a continental margin: The Levant case study, Earth Sci. Rev. 139, 83-103. https://doi.org/10.1016/j.earscirev.2014.08.015. 
Segev A., Sass E., Schattner U. (2018) Age and structure of the Levant Basin, Eastern Mediterranean, Earth Sci. Rev. 182, 233-250. https://doi.org/10.1016/j.earscirev.2018.05.011.

Sharland P.R., Archer R., et al. (2001) Arabian plate sequence stratigraphy, GeoArabia 2, 1-371.

Steckler U., Brink S. (1986) Lithospheric strength variations as a control on new plate boundaries: examples from the northern Red Sea region, Earth Planet. Sci. Lett. 79, 120-132.

Steckler M., Berthelot F., Lyberis N., Le Pichon X. (1988) Subsidence in the Gulf of Suez: implications for rifting and plate kinematics, Tectonophysics 153, 249-270.

Symeou V., Homberg C., Nader F.H., Darnault R., Lecomte J.C., Papadimitriou N. (2017) Longitudinal and temporal evolution of the tectonic style along the Cyprus Arc system, assessed through $2 \mathrm{D}$ reflection seismic interpretation, Tectonics 37, https://doi.org/10.1002/2017TC004667.

Ukla S. (1970) Subsurface Geology and Well Correlation in North and Central Lebanon, MSc Thesis, American University of Beirut, Beirut, pp. 249 p.

Van Wagoner J.C., Posamentier H.W., Mitchum R.M., Vail P.R., Sarg J.F., Loutit T.S., Hardenbol J. (1988) An overview of the fundamentals of sequence stratigraphy and key definitions, in: Wilgus C.K., Hastings B.S., Kendall Ch.St.C.G., Posamentier H.W., Ross C.A., Van Wagoner J.C. (eds),
Sea-level changes - an Integrated Approach, Spec. Publ. Soc. Econ. Paleont. Mineral., 42, pp. 39-45.

Walley C.D. (1998) Some outstanding issues in the geology of Lebanon and their importance in the tectonic evolution of the Levantine region, Tectonophysics 298, 37-62. https://doi.org/10.1016/S0040-1951(98)00177-2.

Weber M., Abu-Ayyash K., et al. (2004) The crustal structure of the Dead Sea transform, Geophys. J. Int. 156, 655-681.

Zeyen H., Fernàndez M. (1994) Integrated lithospheric modeling combining thermal, gravity and local isostacy analysis: application to the NE Spanish Geotransect, J. Geophys. Res. 99, 18089-18102.

Zeyen H., Ayarza P., Fernàndez M., Rimi A. (2005) Lithospheric structure under the western African-European plate boundary: A transect across the Atlas Mountains and the Gulf of Cadiz, Tectonics 24, TC2001, https://doi.org/10.1029/ 2004 TC001639.

Zienkiewicz O.C. (1977) The finite element method, McGraw Hill, New York, p. 787.

Zverev S. (2005) Peculiarities of sediments and basement structure in the frontal zone of the Cyprean Arc (based on seismic refraction data), in: Krasheninnikov V., Hall J., Hirsch F., Benjamini C., Flexer A. (eds), Geological framework of the Levant, Volume II: The Levantine Basin and Israel, Historical Productions-Hall, Chap. 3, pp. 113-126. 